\title{
Interactions between Rainbow Trout Eyed Eggs and Flavobacterium spp. Using a Bath Challenge Model: Preliminary Evaluation of Bacteriophages as Pathogen Control Agents
}

\author{
Valentina L. Donati ${ }^{1, *}$, Inger Dalsgaard ${ }^{1}$, Anniina Runtuvuori-Salmela ${ }^{2}$, Heidi Kunttu ${ }^{2}$, Johanna Jørgensen ${ }^{3}$,

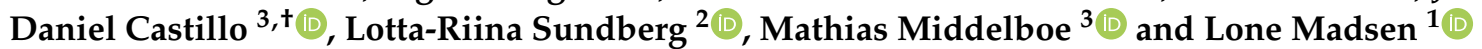 \\ 1 Unit for Fish and Shellfish Diseases, National Institute of Aquatic Resources, \\ Technical University of Denmark, 2800 Kongens Lyngby, Denmark; inda@aqua.dtu.dk (I.D.); \\ loma@aqua.dtu.dk (L.M.) \\ 2 Department of Biological and Environmental Science and Nanoscience Center, University of Jyväskylä, \\ P.O. Box 35, FI-40014 Jyväskylä, Finland; anniina.runtuvuori@jyu.fi (A.R.-S.); heidi.kunttu@jyu.fi (H.K.); \\ lotta-riina.sundberg@jyu.fi (L.-R.S.) \\ 3 Marine Biological Section, Department of Biology, University of Copenhagen, 3000 Helsingør, Denmark; \\ johanna.jorgensen@bio.ku.dk (J.J.); daniel.castillo@bio.ku.dk (D.C.); mmiddelboe@bio.ku.dk (M.M.) \\ * Correspondence: valdo@aqua.dtu.dk \\ † Present address: Instituto de Investigación Interdisciplinar en Ciencias Biomédicas SEK (I3CBSEK), \\ Universidad SEK, Santiago 8340363, Chile.
}

Citation: Donati, V.L.; Dalsgaard, I.; Runtuvuori-Salmela, A.; Kunttu, H.; Jørgensen, J.; Castillo, D.; Sundberg, L.-R.; Middelboe, M.; Madsen, L. Interactions between Rainbow Trout Eyed Eggs and Flavobacterium spp. Using a Bath Challenge Model: Preliminary Evaluation of Bacteriophages as Pathogen Control Agents. Microorganisms 2021, 9, 971. https://doi.org/10.3390/ microorganisms 9050971

Academic Editor: Adelaide Almeida

Received: 27 February 2021

Accepted: 14 April 2021

Published: 30 April 2021

Publisher's Note: MDPI stays neutral with regard to jurisdictional claims in published maps and institutional affiliations.

Copyright: (c) 2021 by the authors. Licensee MDPI, Basel, Switzerland. This article is an open access article distributed under the terms and conditions of the Creative Commons Attribution (CC BY) license (https:// creativecommons.org/licenses/by/ $4.0 /)$.
Abstract: The microbial community surrounding fish eyed eggs can harbor pathogenic bacteria. In this study we focused on rainbow trout (Oncorhynchus mykiss) eyed eggs and the potential of bacteriophages against the pathogenic bacteria Flavobacterium psychrophilum and F. columnare. An infection bath method was first established, and the effects of singular phages on fish eggs was assessed (survival of eyed eggs, interaction of phages with eyed eggs). Subsequently, bacteriachallenged eyed eggs were exposed to phages to evaluate their effects in controlling the bacterial population. Culture-based methods were used to enumerate the number of bacteria and/or phages associated with eyed eggs and in the surrounding environment. The results of the study showed that, with our infection model, it was possible to re-isolate F. psychrophilum associated with eyed eggs after the infection procedure, without affecting the survival of the eggs in the short term. However, this was not possible for F. columnare, as this bacterium grows at higher temperatures than the ones recommended for incubation of rainbow trout eyed eggs. Bacteriophages do not appear to negatively affect the survival of rainbow trout eyed eggs and they do not seem to strongly adhere to the surface of eyed eggs either. Finally, the results demonstrated a strong potential for short term $(24 \mathrm{~h})$ phage control of F. psychrophilum. However, further studies are needed to explore if phage control can be maintained for a longer period and to further elucidate the mechanisms of interactions between Flavobacteria and their phages in association with fish eggs.

Keywords: Flavobacterium psychrophilum; Flavobacterium columnare; rainbow trout; eyed eggs; phagemediated control; bacteriophages

\section{Introduction}

The physical barrier of the thin chorion (zona pellucida) and the thicker inner membrane (zona radiata) of teleost eggs varies in structure and thickness among species [1], and represents the first line of defense against bacterial and viral infections. The wide range of the bacteria that surrounds the eggs will contribute to the early establishment of the fish microbiome [2,3]. Within these microbial communities, pathogenic bacteria such as Cytophaga spp., Flavobacterium spp., Vibrio spp., Pseudomonas spp., and Aeromonas spp. also exist, and may represent threats for the development and survival of the fish [3-6]. In 
aquaculture facilities, egg disinfection protocols are used to decrease the risk of mortality and pathogen transmission [7].

The transmission of the freshwater pathogen Flavobacterium psychrophilum [8,9], an etiological agent of rainbow trout fry syndrome (RTFS) and bacterial coldwater disease (BCWD), among fish populations is not fully understood. Both the vertical and the horizontal routes have been suggested to play a role [10-12], and F. psychrophilum has been isolated from milt, ovarian fluids, and in close connection with eggs [12-14], as well as from the surrounding environment of diseased fish [12,15]. Similarly to F. psychrophilum, the freshwater pathogen F. columnare, which causes mortality in wild and culture freshwater fish, characterize the microbial communities of fish, eggs, and the rearing waters (reviewed by [16]). Persistent colonization of eggs by Flavobacteria thus likely increase the probability of bacterial transmission to fish in all production stages, which can lead to important economic losses and the increased use of antibiotics [16]. Both F. psychrophilum and F. columnare cause high mortalities in rainbow trout fry populations (up to 80-90\%), depending on the size of the fish [17-19]. Good husbandry management and egg disinfection have been highlighted as methods to reduce the development of infections among fish in hatcheries [12].

The utilization of virulent bacteriophages (also called phages) [20] to reduce mortality and prevent the spread of bacterial populations among fish and crustaceans at different stages has gained increased attention (reviewed by [21,22]). Phage therapy is considered a potential alternative to antibiotics, aiming to reduce the issues related to the use of antibiotics, and as a preventive measure against the spread of bacterial infections (reviewed by [23]).

Previous studies on phage control of Flavobacterial pathogens in rainbow trout have focused on fry and juvenile stages [24-28]. Here, we report for the first time the use of bacteriophages for reducing these pathogens in connection with rainbow trout eyed eggs. In this work, we explored the potential of using virulent bacteriophages targeting F. psychrophilum and F. columnare as bacterial control agents in rainbow trout eyed eggs. At first, we established a bacterial challenge bath method (Section A), and secondly, we evaluated the effects of phage addition on eyed eggs (Section B). Subsequently, we exposed rainbow trout eyed eggs to phages to assess their efficiency in eliminating the target bacterium (Section $\mathrm{C}$ ).

\section{Materials and Methods}

\subsection{Bacteria}

Flavobacterium psychrophilum 950106-1/1 and 160401-1/5N, Danish strains isolated from rainbow trout, were selected for the experiments. F. psychrophilum $950106-1 / 1$ is a well-characterized strain isolated in 1995 (serotype Fd, virulent) [10,29-31], while F. psychrophilum 160401-1/5N was isolated in 2016 and recently characterized (serotype Th, virulent) [31]. An additional strain, F. psychrophilum FPS-S6 (serotype Th, virulent, isolated in 2017 in Sweden), was used for the production of high titer phage FPSV-D22 solutions since it was the most efficient host for phage proliferation $[27,31]$. The strains were stored at $-80{ }^{\circ} \mathrm{C}$ in tryptone yeast extract salts (TYES) medium [32] and glycerol (15-20\%). For phage analysis, F. psychrophilum 950106-1/1 (and F. psychrophilum 160401-1/5N for Exp. I section C) was inoculated in TYES broth ( $5 \mathrm{~mL}$, referred as TYES-B) from a $-80{ }^{\circ} \mathrm{C}$ stock, incubated for $48-72 \mathrm{~h}\left(15^{\circ} \mathrm{C} ; 100 \mathrm{rpm}\right)$ and then streaked onto TYES agar (TYES-B with 1.1\% agar, referred as TYES-A). Single colonies were then picked (3-4 days of incubation) and inoculated in TYES-B for $48 \mathrm{~h}$ [27]. For bath challenge experiments, the selected bacteria were prepared according to [30]. Specifically, $0.5 \mathrm{~mL}$ of a $72 \mathrm{~h}$ bacterial culture $(5 \mathrm{~mL})$ was transferred into $100 \mathrm{~mL}$ TYES-B and incubated at $15{ }^{\circ} \mathrm{C}$. After $48 \mathrm{~h}$ of incubation, appropriate dilutions depending on the selected dose of infection were performed prior to the bath. CFU were counted before and after the infection procedure in duplicates.

Two virulent isolates were used in the studies with F. columnare: B480 and B185. Originally, both strains were isolated from fish farms during columnaris disease outbreaks 
in Finland. Strain B480 was isolated from rainbow trout in 2012, and belongs to the genetic group E [33]. B185 was isolated from rearing tank water in 2008 [34]. Bacterial cultures were stored at $-80{ }^{\circ} \mathrm{C}$ with $10 \%$ glycerol and $10 \%$ fetal calf serum. For the experiments, bacteria were revived from $-80{ }^{\circ} \mathrm{C}$ by inoculation into $5 \mathrm{~mL}$ of Shieh medium [35] and cultured overnight at $25^{\circ} \mathrm{C}$ under constant agitation (120 RPM). Bacteria were enriched by subculturing (1:10) and incubating for $24 \mathrm{~h}$. Bacterial cell density was measured as an optical density (OD, $595 \mathrm{~nm}$; Multiscan FC Thermo Scientific, Ratastie, Finland) and colony forming units per $\mathrm{ml}\left(\mathrm{CFU} \mathrm{mL} \mathrm{mL}^{-1}\right)$ estimated based on our previously determined OD-CFU relationship (unpublished).

\subsection{Bacteriophages}

F. psychrophilum-targeting lytic bacteriophages FpV4 (isolated in 2005 in Denmark from water with feces samples, Podoviridae family) [36,37] and FPSV-D22 (isolated in 2017 in Denmark from fish tissue samples, Siphoviridae family) [27,31] were selected for the studies. Solutions of FpV4 and FPSV-D22 were purified ( $0.2 \mu \mathrm{m}$ pore size sterile filter) and stored in SM buffer $\left(8 \mathrm{mM} \mathrm{MgSO}_{4}, 50 \mathrm{mM}\right.$ Tris-Cl [pH 7.5], $99 \mathrm{mM} \mathrm{NaCl}, 0.01 \%$ gelatin) and glycerol $(15 \%)$ at $-80{ }^{\circ} \mathrm{C}[31,36]$. For the experiments in section $\mathrm{B}$, phage high titer solutions were prepared from crude lysates following the infection of the strain 950105-1/1 (for FpV4 propagation) and of the strain FPS-S6 (for FPSV-D22 propagation) in TYES-B (MOI = 1). After incubation for $48-72 \mathrm{~h}$, the lysed cultures were then centrifuged $\left(5000 \times g, 10 \mathrm{~min}, 4^{\circ} \mathrm{C}\right)$ and filtered with a $0.2 \mu \mathrm{m}$ pore size sterile filter (Sterivex, Millipore; Merck KGaA, Darmstadt, Germany). For the experiments in section B and C, FpV4 and FPSV-D22 crude lysates were further purified and concentrated by PEG-precipitation (24 hincubation at $4{ }^{\circ} \mathrm{C}$ with poly-ethylene glycol 8000 (PEG-8000) and sodium chloride at a final concentration of $10 \% w / v$ and $1 \mathrm{M}$, respectively) and subsequent $0.2 \mu \mathrm{m}$ filtration, centrifugation $\left(10,000 \times g, 30 \mathrm{~min}, 4^{\circ} \mathrm{C}\right)$, and re-suspension in either sterile TYES-B or sterile SM buffer, as described by $[27,38]$.

F. columnare-infecting lytic Myoviridae phages FCL-2 (isolated in 2008 in Finland, infection of hosts in genetic group G) [34] and FCOV-F27 (isolated in 2017 in Finland, infection of hosts in genetic group C) [33] were used in the experiments (phages were previously isolated from tank water in fish farms during columnaris outbreaks). FCL-2 has previously been shown effective against columnaris infections in rainbow trout [28]. To test the interaction with rainbow trout eggs (section B, experiment III), crude lysates of each phage were produced, as described earlier [28]. To test the efficiency of phages in preventing F. columnare replication on eggs, the phage FCL-2 was produced and purified by tangential flow filtration with diafiltration by PhageCosultants Ltd. Briefly, $300 \mathrm{~mL}$ of the crude lysate was loaded on the Millipore Labscale Tangential Flow Filtration (TFF) System with Pellicon ${ }^{\circledR}$ XL Ultrafiltration Module Biomax ${ }^{\circledR} 100 \mathrm{kDa}, 0.005 \mathrm{~m}^{2}$. The lysate was diafiltrated by using ultrafiltration membranes (PES, $100 \mathrm{kDa}$ pass) to completely remove or lower the concentration of salt, solvent, and metabolites by exchanging the volume of the lysate to $0,9 \% \mathrm{NaCl}$ three times.

\subsection{Rainbow Trout Eyed Eggs}

Rainbow trout (Oncorhynchus mykiss) eyed eggs (>200 day degrees, $\mathrm{dd}$ ) used for the experiments concerning F. psychrophilum and its phages were purchased from Troutex ApS (Egtved, Denmark). A few hours after arrival at the laboratory (Denmark), the experiments were performed. The status of the eyed eggs was inspected to reveal if any mortality had occurred during the transportation, whereafter the eggs were disinfected according to standard procedures performed at Danish rainbow trout hatcheries (10-15 min treatment in a iodine-based disinfectant for aquaculture) (100 ppm active iodine; 1\% Actomar K30 (Desag AF, Uster, Switzerland)) [15] (Figure 1A). After disinfection, the eyed eggs were rinsed with sterile water before the bacteria and phage exposure experiments. 


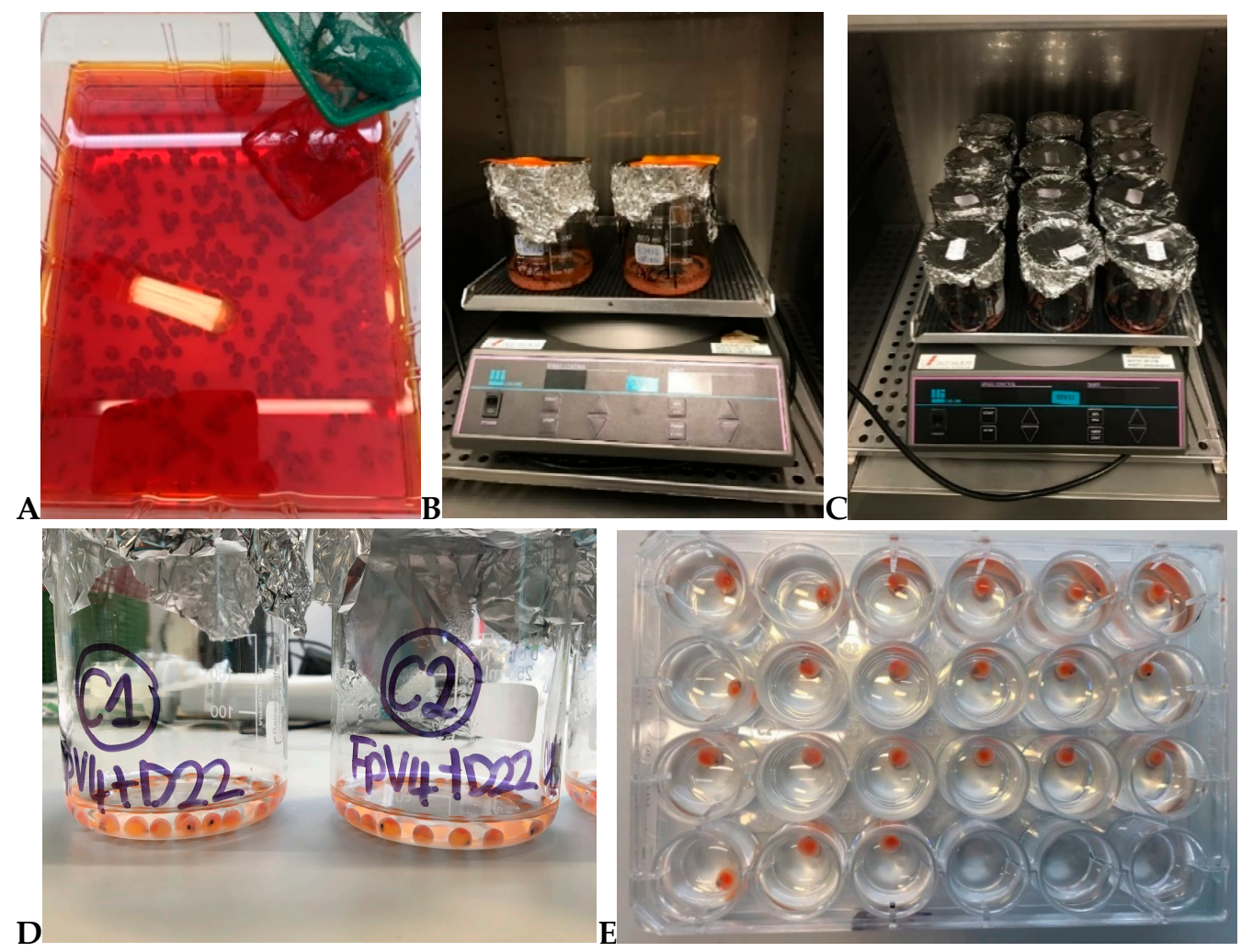

Figure 1. Illustrated overview of the experimental procedure followed in the various experiments concerning F. psychrophilum and its phages. (A) Disinfection of eyed eggs following standard procedures used in hatchery facilities (iodine-based solution) performed at the start of each experiment; (B) eyed eggs during the two-hour bacterial bath challenge with F. psychrophilum and incubation at $10{ }^{\circ} \mathrm{C}$ (experiments section $\mathrm{A}$ and $\mathrm{C}$ ); (C) eyed eggs during the phage bath and incubation at $10{ }^{\circ} \mathrm{C}$ (experiments section B and C); (D) eyed eggs for phage bath placed in $250 \mathrm{~mL}$ sterile glass beakers (experiments section $B$ and C); (E) eyed eggs during incubation in 24-well plates (experiments section A, B, and C) (photos by V.L. Donati).

For the experiments concerning F. columnare and its phages, rainbow trout eyed eggs (>200 day degrees, dd) were received from a fish farm within a one-hour drive from the laboratory (Finland). The eggs were disinfected with the iodine-based disinfectant Buffodine $^{\circledR}$ (Evans Vanodine International plc, Lancashire, UK) at the farm according to the manufacturer's instructions (10 min treatment), cold-transported to the lab, and used immediately in the experiments. Before the start of an experiment, six eggs were sampled for the presence of F. columnare and its phages and found negative.

\subsection{Establishment of a Bath Bacterial Challenge Method (Section A)}

A series of experiments was initially performed to establish a reproducible method to study the interactions of F. psychrophilum and rainbow trout eyed eggs at a small scale. These experiments were performed with the aim of (1) isolating the bacterium in connection with the eggs and (2) recording the effects of the bacterial challenge on the eggs' survival during $24 \mathrm{~h}$ incubations. An additional experiment, focused on F. psychrophilum growth in different media, was performed. Furthermore, experiments targeting F. columnare were set up with the aim of evaluating the effects of temperature and medium on the eggs' survival.

F. psychrophilum 950106-1/1 was chosen for the preliminary experiments. Disinfected eyed eggs were placed in $500 \mathrm{~mL}$ sterile glass beakers containing $200 \mathrm{~mL}$ of either bacterial solution (Exp. no. 1: $8.7 \times 10^{4} \mathrm{CFU} \mathrm{mL}^{-1}$; Exp. no. 2: $1.5 \times 10^{7} \mathrm{CFU} \mathrm{mL}^{-1}$; Exp. no. 3: $1.6 \times 10^{5} \mathrm{CFU} \mathrm{mL}{ }^{-1}$ ) or sterile TYES-B (control for the infection) and incubated for $2 \mathrm{~h}$ at $10^{\circ} \mathrm{C}$ at $80-90$ RPM (Figure 1B). After the bath challenge procedure, the eyed eggs 
were moved to sterile 24-well plates (one egg per well) (CELLSTAR ${ }^{\circledR}$, Greiner Bio-One $\mathrm{GmbH}$, Frickenhausen, Germany) containing $2 \mathrm{~mL}$ of sterile TYES-B (Exp. no. 1), sterile Milli-Q water (Exp. no. 2), or sterile SM buffer diluted 10 times in Milli-Q water (Exp. no. 3). Eyed eggs were transferred using sterile $10 \mu \mathrm{L}$ inoculation loops (Figure 1E). The plates were covered with lids and incubated at $10{ }^{\circ} \mathrm{C}$ (at 80-90 RPM) for $24 \mathrm{~h}$. In Exp. no. 1 , three eggs were sampled at $1,3,21$, and $25 \mathrm{~h}$ after the incubation in 24 -well plates. In Exp. no. 2 and no. 3, three eggs were sampled right after the end of the bacterial bath (before the transfer to 24 -well plates) and after $24 \mathrm{~h}$ of incubation. Exp. no. 1 was performed in December 2018, Exp. no. 2 in May 2019, and Exp. no. 3 in June 2019. Furthermore, to evaluate the growth of F. psychrophilum 950106-1/1 in Milli-Q water and $0.2 \mu \mathrm{m}$ filtered tank water collected in our fish experimental facilities and compare to the growth in TYES medium, a growth experiment was performed as follows: $0.5 \mathrm{~mL}$ of a $72 \mathrm{~h}$ bacterial culture $(5 \mathrm{~mL})$ was transferred into either $100 \mathrm{~mL}$ of Milli-Q water, $100 \mathrm{~mL}$ of water from fish experimental facilities (fish tanks), or sterile TYES-B, and incubated at $15^{\circ} \mathrm{C}$. The experiment was performed in duplicates and the CFU count was performed at various time points.

In the case of F. columnare, various temperatures $\left(5{ }^{\circ} \mathrm{C}\right.$ (moved to $10{ }^{\circ} \mathrm{C}$ after $\left.72 \mathrm{~h}\right)$, $15^{\circ} \mathrm{C}$, and $20^{\circ} \mathrm{C}$ ), in combination with different media (pre-aerated with pressurized air until $100 \%$ oxygen saturation, non-aerated sterile distilled water, or pre-aerated or nonaerated sterile Shieh medium) were tested (February 2019). For each group, 12 eyed eggs were placed in sterile 24-well plates (Nunc ${ }^{\mathrm{TM}}$, Thermo Fisher Scientific, Rochester, USA) containing $2 \mathrm{~mL}$ of the selected medium and incubated at the settled temperature without any shaking (similarly as for F. psychrophilum in Figure 1E). Four of the 12 eyed eggs in each group were exposed to the F. columnare strain B480 by adding $10 \mu \mathrm{L}$ of overnight culture $\left(1.0 \times 10^{8} \mathrm{CFU} \mathrm{mL}{ }^{-1}\right)$ directly to the wells, giving a final density of $5.0 \times 10^{5} \mathrm{CFU} \mathrm{mL}^{-1}$. Survival of the eggs (embryo movement and blood flow observed under a light microscope) was followed in $24 \mathrm{~h}$ intervals for $144 \mathrm{~h}$, except for the experiments performed at $20^{\circ} \mathrm{C}$, which were carried out until $72 \mathrm{~h}$. In the case of bacterial exposure, samples from the media surrounding the eggs were collected from at least two wells per treatment at 24,48 , and $96 \mathrm{~h}$.

\subsection{Interactions of Phages with Rainbow Trout Eyed Eggs (Section B)}

In this section, the effects of phages on rainbow trout eyed eggs' survival in the absence of pathogens were evaluated. The experiments were also aimed at evaluating if phages could interact with the surface of the eggs. The effects of two selected F. psychrophilum bacteriophages (FpV4 and FPSV-D22; singularly) were tested by constant (Exp. I, section B) and by short-term bath exposure (Exp. II, section B). Similarly, the effects of two selected F. columnare bacteriophages (FCL-2 and FCOV-F27, singularly; Exp. III, section B) were tested. An overview of the experiments performed in this section is presented in Table 1.

\subsubsection{Constant Exposure of Eyed Eggs to F. psychrophilum Phages (Exp. I, Section B)}

Eyed eggs were constantly exposed to phages FpV4 $\left(3.0 \times 10^{5} \mathrm{PFU} \mathrm{mL}^{-1}\right.$ crude lysate and $1.0 \times 10^{6}$ PFU mL ${ }^{-1}$ PEG-purified in TYES-B) and FPSV-D22 $\left(1.2 \times 10^{7} \mathrm{PFU} \mathrm{mL}^{-1}\right.$ PEG-purified in TYES-B) for $144 \mathrm{~h}$ (the experiment was performed in April 2019). A control group without phage exposure was included (eggs were placed in sterile TYESB). After disinfection, seventy-five eyed eggs were placed in 24-well plates using sterile $10 \mu \mathrm{L}$ inoculation loops (all groups contained 23 eggs except the group where eggs were exposed to FpV4 in crude lysate where 16 eggs were incubated) with $2 \mathrm{~mL}$ of phage solution (sterile TYES broth for the control) (Figure 1E). Covered with lids, the plates were incubated at $10^{\circ} \mathrm{C}$ at 80-90 RPM. After 2, 27, 49, and $71 \mathrm{~h}$ of incubation, three eggs and their correspondent well content per group were collected. At $144 \mathrm{~h}$ after the start of the experiment, the status of three eggs (alive/dead; hatched/not hatched) was characterized, and only the well content was collected for phage analysis. 
Table 1. Overview of studies focused on exploring the interactions between rainbow trout eyed eggs and Flavobacterium spp. bacteriophages (section B and C).

\begin{tabular}{|c|c|c|c|c|}
\hline Study Name & $\begin{array}{c}\text { Infection with } \\
\text { Flavobacterium spp. }\end{array}$ & $\begin{array}{c}\text { Type of } \\
\text { Exposure to Phages }\end{array}$ & Phages & $\begin{array}{c}\text { Type of } \\
\text { Preparation }\end{array}$ \\
\hline $\begin{array}{c}\text { Exp. I } \\
\text { Section B }\end{array}$ & No & Constant & $\begin{array}{c}\text { FpV4 and FPSV-D22 } \\
\text { (singularly) }\end{array}$ & $\begin{array}{c}\text { Crude lysates and } \\
\text { PEG-purified in sterile } \\
\text { TYES-B }\end{array}$ \\
\hline $\begin{array}{c}\text { Exp. II } \\
\text { Section B }\end{array}$ & No & $4 \mathrm{~h}$ bath & $\begin{array}{c}\text { FpV4 and FPSV-D22 } \\
\text { (singularly) }\end{array}$ & Crude lysates \\
\hline $\begin{array}{c}\text { Exp. III } \\
\text { Section B }\end{array}$ & No & 30 min bath; constant & $\begin{array}{l}\text { FCL-2 and FCOV-F27 } \\
\text { (singularly) }\end{array}$ & Crude lysates \\
\hline $\begin{array}{c}\text { Exp. I } \\
\text { Section C }\end{array}$ & Yes & $48 \mathrm{~h}$ bath & $\begin{array}{c}\text { FpV4 and FPSV-D22 } \\
\text { (mixed 1:1) }\end{array}$ & PEG-purified in SM buffer \\
\hline $\begin{array}{c}\text { Exp. II } \\
\text { Section C }\end{array}$ & Yes & $\begin{array}{l}2 \text { h bath; } \\
\text { constant }\end{array}$ & FCL-2 & Diafiltration \\
\hline
\end{tabular}

\subsubsection{Bath Exposure of Eyed Eggs to F. psychrophilum Phages (Exp. II, Section B)}

In this experiment (performed in April 2019), eighty-one rainbow trout eyed eggs were bathed for $4 \mathrm{~h}$ at $10^{\circ} \mathrm{C}$ at $80-90 \mathrm{RPM}$ either in phage solutions $\left(1.9 \times 10^{7} \mathrm{PFU} \mathrm{mL}^{-1}\right.$ FpV4 or $8.2 \times 10^{7} \mathrm{PFU} \mathrm{mL}^{-1}$ FPSV-D22 crude lysates) or in sterile TYES-B, for the control group. The bath procedures were performed in $250 \mathrm{~mL}$ sterile glass beakers containing $80 \mathrm{~mL}$ of phage or control solution (27 eggs for each treatment) (Figure 1C). After phage exposure, eggs were subdivided into 24-well plates (24 eggs per group) with $2 \mathrm{~mL}$ sterile Milli-Q water (one egg per well) using sterile $10 \mu \mathrm{L}$ inoculation loops. Plates were covered and incubated at $10^{\circ} \mathrm{C}$ at 80-90 RPM for $144 \mathrm{~h}$ (Figure 1E). At $0 \mathrm{~h}$ and 24, 46, and $68 \mathrm{~h}$ after the end of phage bath exposure, three eggs and their correspondent well content per group were collected for further phage analysis. At $144 \mathrm{~h}$, the status of three eggs (alive/dead; hatched/not hatched) was characterized, and only the well content was sampled for phage analysis.

2.5.3. Bath and Constant Exposure of Eyed Eggs to F. columnare Phages (Exp. III, Section B)

Eyed eggs were exposed to phages FCL-2 or FCO-F27 $\left(1.0 \times 10^{9} \mathrm{PFU} \mathrm{mL}^{-1}\right.$; crude lysates) diluted in either sterile distilled water or in Shieh medium at $10^{\circ} \mathrm{C}$. Phage exposure was performed by either a $30 \mathrm{~min}$ bath in a Petri dish ( $40-50 \mathrm{~mm} \varnothing, 15 \mathrm{~mL}$ medium volume, at $60 \mathrm{RPM}$ ) or constant exposure in 24-well plates (no shaking). Eggs without phage treatment and a phage lysate without eggs served as controls. For constant exposure and after the phage bath, eggs (8 per group) were individually placed in 24-well plates containing $2 \mathrm{~mL}$ of either sterile distilled water or Shieh medium (similarly as for F. psychrophilum in Figure 1E). Bathed eggs were moved into wells with only medium (distilled water or Shieh medium). Eyed eggs for constant exposure experiments were moved directly to wells containing the phages. Eyed eggs were moved using sterile disposable forceps. Survival of the eggs was determined at $0,24,48$, and $96 \mathrm{~h}$. Phage density was determined both from eggs and the corresponding well content at 0,24 , and $48 \mathrm{~h}$.

\subsection{Evaluation of Phages as Pathogen Control Agents (Section C)}

In this section, the experiments were aimed at assessing the potential of phages as pathogen control agents (an overview is presented in Table 1). The effects of two selected F. psychrophilum phages (FpV4 and FPSV-D22; mixed 1:1) in controlling F. psychrophilum 950106-1/1 and the strain 160401-1/5N were tested by a $48 \mathrm{~h}$ bath exposure (Exp. I, section C). Similarly, the effects of the F. columnare phage FCL-2 in controlling F. columnare B185 were tested by either constant or bath phage exposures (Exp. II, section C). 


\subsubsection{Phage Bath of F. psychrophilum Challenged Eggs (Exp. I, Section C)}

F. psychrophilum bath-challenged eyed eggs were exposed to a two-component phage solution (phages FpV4 and FPSV-D22 mixed 1:1) for $48 \mathrm{~h}$ and then transferred to individual wells for the examination of phage and pathogen abundance (experimental set up presented in Figure A1). The experiment was performed in June 2020.

At first, eyed eggs were bath-challenged $\left(2 \mathrm{~h}, 10^{\circ} \mathrm{C}, 80-90 \mathrm{RPM}\right)$ either with F. psychrophilum strain $950106-1 / 1$ or the strain $160401-1 / 5 \mathrm{~N}$ at a concentration of $2.0 \times 10^{6} \mathrm{CFU} \mathrm{mL}^{-1}$. Control eggs were placed in sterile TYES-B. To perform the challenge, 135 disinfected eyed eggs were placed in $600 \mathrm{~mL}$ sterile glass beakers containing $200 \mathrm{~mL}$ of bacterial solution or sterile TYES-B (Figure 1B). Subsequently, eyed eggs were moved to $250 \mathrm{~mL}$ sterile glass beakers (30 eggs per beaker) containing either the selected phage solution $(20 \mathrm{~mL}$ ) or the phage bath controls ( $20 \mathrm{~mL}$ of sterile SM buffer or Milli-Q water) using sterile $10 \mu \mathrm{L}$ inoculation loops (SARSTEDT AG \& Co. KG, Nümbrecht, Germany) (one per group) (Figure 1C). For phage bath procedures, PEG-purified solutions of phage FpV4 and FPSV-D22 at a concentration of $3.9 \times 10^{8} \mathrm{PFU} \mathrm{mL} \mathrm{m}^{-1}$ and $1.3 \times 10^{9} \mathrm{PFU} \mathrm{mL}^{-1}$, respectively, were mixed 1:1 to a final concentration of $2.2 \times 10^{9} \pm 1.6 \times 10^{9} \mathrm{PFU} \mathrm{mL}^{-1}$ (phage bath no. 1 ) and diluted 10 times in SM buffer for phage bath no. 2 (final concentration of $1.3 \times 10^{8} \pm 4.8 \times 10^{7} \mathrm{PFU} \mathrm{mL}^{-1}$ ). The selected volume $(20 \mathrm{~mL})$ was considered enough to cover the eggs during the incubation (Figure 1D). After a $48 \mathrm{~h}$ incubation at $10^{\circ} \mathrm{C}$ (at 80-90 RPM), eggs were divided in 24-well plates containing $2 \mathrm{~mL}$ of sterile Milli-Q water (one egg per well) with the help of sterile $10 \mu \mathrm{L}$ inoculation loops (one per egg) (Figure 1E). Plates were covered with lids and incubated at $10^{\circ} \mathrm{C}$ at $80-90 \mathrm{RPM}$.

Eyed eggs and the corresponding bath or well content were sampled for bacteria and /or phage quantification at the end of the bacterial challenge ( $0 \mathrm{~h}$ post infection, hpi), during phage exposure (24 and $48 \mathrm{hpi}$ ) and during the subsequent incubation in 24-well plates (72 and $144 \mathrm{hpi}$ ). For the sampling points 0 and $24 \mathrm{hpi}$, six eggs were sampled and, during the sampling procedure of three of them, an additional drying step was included. For the following sampling points, three eggs were collected and sampled without any drying step.

\subsubsection{Phage Exposure of F. columnare Challenged Eggs (Exp. II, Section C)}

F. columnare strain B185 and its phage FCL-2 (purified by diafiltration and diluted in $\mathrm{NaCl} 0.9 \%$ ) were used in the experiment where eyed eggs were exposed to phages after (upper panel in Figure A2) or before the bacterial challenge (lower panel in Figure A2). Ion-exchanged water was used as a medium for the eggs, and the temperature was $10^{\circ} \mathrm{C}$.

At first, eyed eggs were bathed for $2 \mathrm{~h}$ (at $60 \mathrm{RPM}$ ): (a) with F. columnare B185 $\left(5.0 \times 10^{6} \mathrm{CFU} \mathrm{mL} \mathrm{mL}^{-1}\right)$ or with sterile Shieh medium (diluted in ion-exchange water in the same extent as done for the bacterium) in $140 \mathrm{~mm}$ diameter Petri dishes (SARSTEDT AG \& Co. KG, Nümbrecht, Germany) (97-99 eggs per dish-100 mL volume), or else (b) with the phage FCL-2 $\left(2.5 \times 10^{7} \mathrm{PFU} \mathrm{mL}{ }^{-1}\right)$ or with $\mathrm{NaCl}(0.09 \%)$ in $90 \mathrm{~mm}$ diameter Petri dishes ( 24 eggs per dish-35 mL volume). After the baths, the eggs were moved with sterile forceps in $140 \mathrm{~mm}$ diameter Petri dishes (22-25 eggs per dish-100 mL volume) containing water and incubated overnight without agitation. In addition, 24 additional eggs (12 per each group) were placed directly in 24-well plates containing water or $\mathrm{NaCl}(0.09 \%)$ without any preliminary bath procedure and observed constantly during the experiment. After the overnight incubation, the viability of all the eggs was checked and, in the bath bacterial challenge groups, 3 eggs and their corresponding well content (per treatment: + or $-F$. columnare) were sampled to quantify the bacterial densities and the phage titers.

Following the overnight incubation, eyed eggs previously exposed to F. columnare were either bathed for $2 \mathrm{~h}$ or moved directly into 24-well plates in either FCL-2 phage solution $\left(2.5 \times 10^{7} \mathrm{PFU} \mathrm{mL}{ }^{-1}\right)$ or $\mathrm{NaCl}(0.09 \%)$ (24 eggs per group). Eyed eggs previously exposed to phages were bath-exposed to F. columnare strain B185 $\left(5.0 \times 10^{6} \mathrm{CFU} \mathrm{mL} \mathrm{mL}^{-1}\right)$ or sterile Shieh medium for $2 \mathrm{~h}$ (12 eggs per group). Bath exposures to either phages or bacteria were performed in $90 \mathrm{~mm}$ diameter Petri dishes ( $35 \mathrm{~mL}$ volume) at $60 \mathrm{RPM}$. 
Following the $2 \mathrm{~h}$ bath, eyed eggs were transferred to 24-well plates containing $2 \mathrm{~mL}$ of water (one per well). In the part of the experiment where eyed eggs were at first exposed to the bacterium and then to the phages (constantly or by bath), the viability of the eggs was observed immediately after transferring the eggs to 24-well plates and then at $24 \mathrm{~h}$ intervals until $144 \mathrm{~h}$. In addition, three eggs and their corresponding well content were sampled at 0,24 , and $48 \mathrm{~h}$ to quantify the bacterial densities and the phage titers.

\subsection{Eyed Eggs Sampling Procedure}

The graphical overview in Figure 2 refers to the eyed eggs sampling procedure followed in the experiments concerning F. psychrophilum and its phages. Additional information in relation to F. columnare are presented at the end of this paragraph.

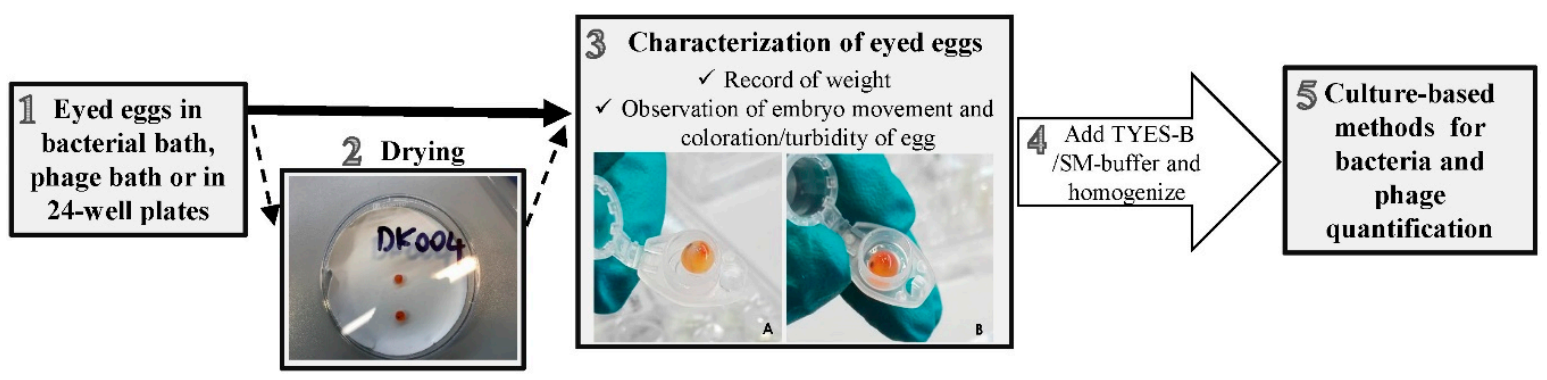

Figure 2. Graphical flow of the eyed eggs sampling procedure in relation to the experiments focused on F. psychrophilum and its phages. (1) Eyed eggs placed in the bacterial bath, the phage bath, or in 24-well plates were sampled at the selected time points. (2) A drying step was included for a selected number of eggs in Exp. I in section C. (3) Eyed eggs were characterized (A: example of turbid egg; B: example of normal coloration). (4) Sampled eggs were processed and homogenized. (5) According to the scope of the experiment, bacteria were enumerated and samples for phage analysis stored.

The sampling procedure was developed based on the previous work of [39-41]. Eyed eggs placed in the bacterial bath, the phage bath, or in 24-well plates (Figure 2 step 1) were collected at the selected time points using a sterile $10 \mu \mathrm{L}$ inoculation loop (SARSTEDT AG \& Co. KG, Nümbrecht, Germany) and placed in pre-weighted sterile $1.5 \mathrm{~mL}$ micro tubes (SARSTEDT AG \& Co. KG, Nümbrecht, Germany) (Figure 2 step 3). For the Exp. I in section C, a drying step was included for a selected number of eggs (Figure 2 step 2), which were placed on sterile filter paper for a few seconds (Whatman ${ }^{\circledR}$ cat. no. 1003 090, Cytiva, Marlborough, USA) and then transferred to sterile $1.5 \mathrm{~mL}$ micro tubes. The weight was recorded and sampled eggs were characterized by observing the embryo movement and by recording the coloration/presence of turbidity of the egg (Figure 2 step 3). Dead eggs were identified by a whitish/opaque coloration, as previously described [40]. Sampled eggs were then cut and fragmented with the use of sterile scissors, and a fixed volume of TYES-B (experiments section A and Exp. II section C) or SM buffer (Exp. I and II section B) was added according to the scope of the experiment. Samples were thereafter homogenized by vortexing (15-20 s) (Figure 2 step 4). Finally, bacteria were enumerated by CFU counts, and the homogenized content was stored for subsequent phage quantification (Figure 2 step 5).

During Exp. I and II in section B, where our aim was to quantify F. psychrophilum phages in connection with the eyed eggs over time, $300 \mu \mathrm{L}$ of sterile SM buffer was added to the sampled eggs (Figure 2 step 4), and after the homogenization procedure, $5 \mu \mathrm{L}$ of chloroform was added and samples were stored for further phage analysis. For each sampled egg, the corresponding well content was also collected for phage analysis (300 $\mu \mathrm{L}$ of well content was placed into sterile $1.5 \mathrm{~mL}$ micro tubes and $5 \mu \mathrm{L}$ of chloroform was added). The well content was streaked on TYES-A and Blood-A plates to assess the growth of bacteria/fungi. TYES-A plates were incubated at $15^{\circ} \mathrm{C}$ and Blood-A plates at $20^{\circ} \mathrm{C}$ for $4-5$ days. 
During the experiments of section A and C (concerning F. psychrophilum), eyed eggs were sampled to quantify solely the bacterium (section A) or both the bacterium and the phages (Exp. I section C) in connection with the eggs. In this case, after egg status characterization (Figure 2 step 3), a fixed volume of sterile TYES-B (300-1000 $\mu \mathrm{L}$ in experiments of section A; $700 \mu \mathrm{L}$ in Exp. I section C) was added to each egg sample and homogenized (Figure 2 step 4). Ten-fold serial dilutions were immediately performed and spread on TYES-A plates in order to estimate the bacterial concentration by CFU counts. Sampled eggs from the bacterial control groups (not exposed to F. psychrophilum) were also plated on TYES-A (no dilutions). For Exp. I section C, $300 \mu \mathrm{L}$ of the homogenized egg samples was transferred into new sterile $1.5 \mathrm{~mL}$ micro tubes (SARSTEDT AG \& Co. KG, Nümbrecht, Germany) and $5 \mu \mathrm{L}$ of chloroform was added for subsequent phage analysis (Figure 2 step 5). In addition, phages and bacteria were also quantified in the corresponding well or bath content of each sampled egg. The concentration of bacteria was determined performing tenfold serial dilutions of the well/bath content directly from the 24-well plate or the beaker used for bath procedures and plated on TYES-A plates. Bath/well content of sampled eggs from the bacterial control groups (not exposed to F. psychrophilum) were also plated on TYES-A (no dilutions). TYES-A plates were incubated at $15^{\circ} \mathrm{C}$ for $4-5$ days and CFU per $\mathrm{mL}$ of solution was estimated. For the Exp. I section $\mathrm{C}, 300 \mu \mathrm{L}$ of the well/bath content was also placed in new sterile $1.5 \mathrm{~mL}$ micro tubes, $5 \mu \mathrm{L}$ of chloroform was added, and the samples were stored at $5{ }^{\circ} \mathrm{C}$ in the dark for subsequent phage quantification. Homogenized eggs and the corresponding bath/well content were streaked on Blood-A to assess the growth of other bacteria/fungi and plates were incubated as mentioned earlier (Exp. I section $C$; only the well content for experiments of section A). The growth of bacteria other than F. psychrophilum on TYES-A plates was recorded (section A and C).

In the experiments concerning F. columnare, the survival of the eyed eggs was followed by observing the embryo movement and, in the experiments in section A, by observing the blood flow by a light microscope. In addition, and as performed for F. psychrophilum, samples for bacterium and phage detection/quantification were collected according to the scope of the experiment. In section A, the well content was streaked on Shieh agar plates, incubated at room temperature for 2 days, and the growth of F. columnare colonies recorded. In the Exp. II section B, the egg samples were processed similarly as for F. psychrophilum. Briefly, eyed eggs were placed in pre-weighted $1.5 \mathrm{~mL}$ Eppendorf tubes and crushed using a Bio Plas homogenization pestle (Thomas Scientific, Swedesboro, NJ, USA). A specific volume of Shieh medium was added (1:10 weight per volume) and the sample was mixed and centrifuged briefly to separate the supernatant, which was stored with chloroform for further phage quantification. For each sampled egg, the corresponding well content was also collected for phage analysis $\left(300 \mu \mathrm{L}\right.$ media samples were stored at $4-6{ }^{\circ} \mathrm{C}$ with $1 \%$ chloroform). Finally, in the Exp. II section $C$, the eggs were not crushed, but were individually vortexed for $10 \mathrm{~s}$ in $400 \mu \mathrm{L}$ of Milli-Q water, of which $100 \mu \mathrm{L}$ was used to detect F. columnare (ten-fold dilutions plated on Shieh agar plates containing $1 \mu \mathrm{g} \mathrm{mL} \mathrm{m}^{-1}$ of tobramycin), and $150 \mu \mathrm{L}$ was stored with chloroform for phage titration.

MALDI-TOF MS (Bruker Daltonic GmbH, Bremen, Germany) was used to confirm that the re-isolated bacteria were F. psychrophilum in doubtful cases, and to identify some of the background bacteria (if present) [42].

\subsection{Detection and Quantification of Bacteriophages}

Bacteriophage detection for phages infecting F. psychrophilum was performed as described by [24,25]. Egg and well content samples were centrifuged for $10 \mathrm{~s}$ at 10,000 RPM at $5{ }^{\circ} \mathrm{C}$ to separate chloroform at the bottom of the tube, and a phage spot method was performed [43]. Four milliliters of TYES soft agar $(0.4 \%$ agar) mixed with $300 \mu \mathrm{L}$ of a 48 h old F. psychrophilum broth culture (in exponential phase) was poured into a TYES-A plate $[25,36]$. Undiluted samples were then spotted in duplicate (section B) or triplicate (section C) $(5 \mu \mathrm{L})$ on a bacterial lawn and incubated at $15^{\circ} \mathrm{C}$ for $3-4$ days. Phages were quantified by counting the plaques in individual spots. In the case of confluent or semi- 
confluent clearing areas, samples were diluted 10 -fold ( $180 \mu \mathrm{L}$ of SM buffer and $20 \mu \mathrm{L}$ of sample) in triplicates and re-spotted on a bacterial lawn as described above.

Bacteriophage quantification for phages infecting $F$. columnare was performed as previously described by [28]. Three hundred microliters of an overnight-grown F. columnare was mixed with $3 \mathrm{~mL}$ of melted Shieh soft agar $(0.7 \%)$ tempered to $47^{\circ} \mathrm{C}$, and poured on Shieh agar plates. Two microliters of the ten-fold dilutions of the phage samples (in sterile Milli-Q water) was spotted on top of the soft agar. Plaques were recorded after incubation for 2 days at room temperature.

\subsection{Statistics}

Statistical significant differences in the bacterial and phage concentrations were tested with GraphPad Prism version 8.4.0 for Windows, (GraphPad Software, San Diego, CA, USA, www.graphpad.com). For meaningful comparisons of two groups, values were compared with a two-tailed unpaired t-test. For comparison of three or more groups, values were compared with ANOVA. $p$-values for multiple comparisons were adjusted for Dunnet correction (adjusted $p$ ). $p$-values $(p)$ below 0.05 were considered significant.

\section{Results}

\subsection{Establishment of a Bath Bacterial Challenge Method (Section A)}

In the first part of our study, we developed an infection bath challenge method for rainbow trout eyed eggs, focusing on F. psychrophilum, with the aim of evaluating fish eggs' survival in the established set up, and the bacterial growth and stability associated with fish eggs and different media (Figure 3, Tables A1 and A2). In addition, since the optimum temperature for $F$. columnare is between $22-29^{\circ} \mathrm{C}$ (depending on the strain) [44], while rainbow trout eyed eggs are normally incubated between 6 and $12{ }^{\circ} \mathrm{C}$ [45], the effects of different temperatures on the eggs' survival were at first evaluated, also in combination with different media (Figure S1).

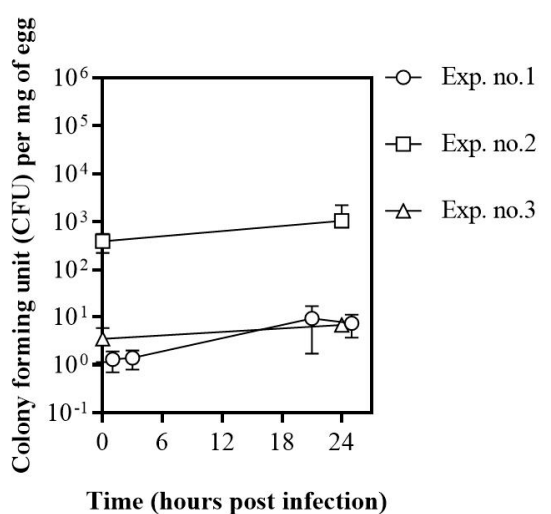
A

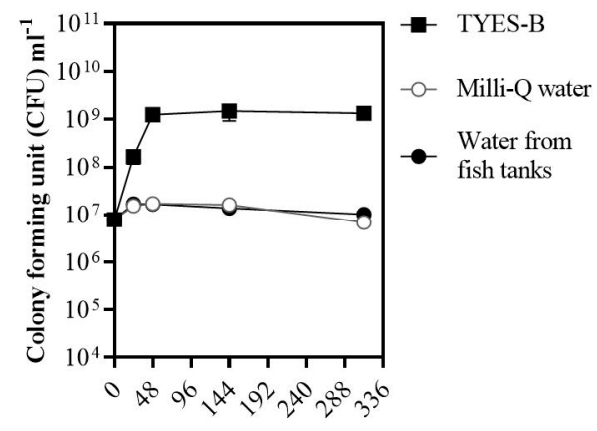

B

Figure 3. F. psychrophilum in connection with the eyed eggs in three independent experiments (section A) (A) and F. psychrophilum growth in Milli-Q and filter-sterilized water from fish tanks in comparison to TYES-B (B). In (A), values represent the mean and standard deviation of three biological replicates except in exp. no. 3 at $24 \mathrm{~h}$ post infection $(n=2)$. Control eyed eggs (bathed with sterile TYES-B) were negative to the bacteria for each experiment. In (B), values represent the mean and standard deviation of two replicates.

In the case of F. psychrophilum, all sampled eggs were characterized as alive based on movement and turbidity indicators (Table A1), and were subsequently recorded to be alive up to 6 days after the start of the experiments (data not shown). F. psychrophilum concentrations in connection with the eyed eggs correlated with the initial bacterial concentration of the bath (Figure 3A). After the bath challenge with $8.7 \times 10^{4} \mathrm{CFU} \mathrm{mL}{ }^{-1}$ (Exp. no. $1,1 \mathrm{~h}$ post infection or hpi) and $1.6 \times 10^{5} \mathrm{CFU} \mathrm{mL}^{-1}$ (Exp. no. 3, $0 \mathrm{hpi}$ ), the 
concentration of F. psychrophilum detected in connection with the eyed eggs was $1.3 \pm 0.6$ and $3.5 \pm 2.4 \mathrm{CFU} \mathrm{\textrm {mg } ^ { - 1 }}$ of egg, respectively. When the eyed eggs were bathed in a higher concentration of bacteria (Exp. no. 2: $1.5 \times 10^{7} \mathrm{CFU} \mathrm{mL}^{-1}$ ), the bacterial concentration on the eggs had increased to $3.9 \times 10^{2} \pm 1.7 \times 10^{2} \mathrm{CFU} \mathrm{mg}{ }^{-1}$ of egg ( 0 hpi). The concentration of bacteria detected in connection with eyed eggs was maintained within $24 \mathrm{~h}$ in the 24-well plates. The detection of bacteria other than F. psychrophilum was recorded, and is presented in Table A2. In additional independent experiments, we observed the growth of F. psychrophilum in Milli-Q and filter-sterilized tank water from fish stables (Figure 3B): the bacteria were not able to actively grow under these conditions, but they remained viable for the tested time frame (15 days).

In the experiments concerning F. columnare (Figure S1), rainbow trout eyed eggs did not survive at $20^{\circ} \mathrm{C}$, and all movement was lost after $24 \mathrm{~h}$ in all the treatments (at $20^{\circ} \mathrm{C}$ ). Fish eggs were characterized as alive until $96-144 \mathrm{~h}$ when placed in water at 5 and $15^{\circ} \mathrm{C}$. The presence of nutrients (Shieh medium) reduced the time of egg survival. When the eggs were spiked with F. columnare, their survival was not affected and the bacteria could be isolated in the eggs incubated at 15 and $20^{\circ} \mathrm{C}$ up to at least $48 \mathrm{hpi}$. At $5^{\circ} \mathrm{C}, \mathrm{F}$. columnare could be isolated only at $24 \mathrm{hpi}$. Based on these results, the subsequent experiments concerning F. columnare and its phages were performed at $10^{\circ} \mathrm{C}$.

\subsection{Interactions of Phages with Rainbow Trout Eyed Eggs (Section B)}

\subsubsection{Constant Exposure of Eyed Eggs to F. psychrophilum Phages (Exp. I, Section B)}

The tested phages did not seem to negatively affect the eggs' survival (Table 2A). Sampled eggs were characterized as alive up to 49 and $71 \mathrm{~h}$ in all groups (only one egg out of 3 exposed to FpV4 in crude lysate was dead at $71 \mathrm{~h}$ ). However, the embryo movement was not observed for a higher number of eggs exposed to the crude lysate compared to the other groups. In addition, at the termination of the experiment $(144 \mathrm{~h})$, most of the eggs in the sampled wells were dead except for two out of three in the PEG-purified FpV4 solution (hatched and alive) and one in the control group (not hatched and alive). Phages were diluted in sterile TYES-B, and this could have stimulated the growth of other bacteria/fungi (Table A3).

Two hours post constant phage exposure (Figure 4A), phages FpV4 and FPSV-D22 were detected in connection with the eyed eggs at a concentration of $4.4 \pm 2.7 \mathrm{PFU} \mathrm{mg}^{-1}$ (FpV4 in crude lysate), $9.2 \pm 3.3 \mathrm{PFU} \mathrm{mg}^{-1}$ (PEG-purified FpV4) and $3.2 \times 10^{3} \pm 2.2 \times 10^{2} \mathrm{PFU} \mathrm{mg}^{-1}$ (PEG-purified FPSV-D22). The concentration of phages in connection with the eggs and in the corresponding wells was maintained over time in the groups with one exception (Figure 4A): the concentration of FpV4 associated with the eggs in the PEG-purified solution increased over time (adjusted $p=0.0184$ ). No phages were detected in the control group.

To summarize, we observed that the tested phages did not seem to negatively affect the eyed eggs' survival, and that the concentration of phage FpV4 in connection with the eyed eggs increased over time.

\subsubsection{Bath Exposure of Eyed Eggs to F. psychrophilum Phages (Exp. II, Section B)}

Similarly to what was observed during constant phage exposure experiments (Exp. I section B), the survival of eyed eggs was not negatively affected when the eggs were bathed with either FpV4 $\left(1.9 \times 10^{7} \mathrm{PFU} \mathrm{mL}^{-1}\right)$ or FPSV-D22 $\left(8.2 \times 10^{7} \mathrm{PFU} \mathrm{mL}^{-1}\right)$ in crude lysates for four hours and then transferred to 24-well plates with sterile Milli-Q water (Table 2B). However, eggs were alive in all groups until the end of the experiment except one in the FPSV-D22 group at $144 \mathrm{~h}$. Bacterial/fungal growth associated with the well content was detected firstly at 68 and $144 \mathrm{~h}$ in all three groups (Table A4). 
Table 2. Exp. I and II, section B: survival of rainbow trout eyed eggs exposed to phage FpV4 and FPSV-D22. In (A), characteristics of the eyed eggs during constant phage exposure (Exp. I). In (B), characteristics of the eyed eggs after a $4 \mathrm{~h}$ phage bath (B, Exp. II). FpV4 and FPSV-D22 were diluted in sterile TYES-B. In yellow: not clear if the egg is alive (no movement and/or light turbidity); in red: the egg is dead (no movement and positive turbidity); not highlighted: the egg is alive. Time $=$ hours of constant phage exposure in $\mathbf{A}$ and hours post-phage bath in $\mathbf{B}$.

\begin{tabular}{|c|c|c|c|c|c|c|c|c|c|c|c|c|c|}
\hline \multicolumn{14}{|c|}{ (A) Constant Phage Exposure (Exp. I Section B) } \\
\hline \multirow{3}{*}{$\begin{array}{l}\text { Time } \\
\text { (h) }\end{array}$} & \multirow{3}{*}{$\begin{array}{c}\text { Evaluated } \\
\text { Parameters }\end{array}$} & \multicolumn{6}{|c|}{ FpV4 } & \multirow{2}{*}{\multicolumn{3}{|c|}{$\begin{array}{c}\text { FPSV-D22 } \\
\text { PEG-Purified }\end{array}$}} & \multicolumn{3}{|c|}{ Control } \\
\hline & & \multicolumn{3}{|c|}{ Crude Lysate } & \multicolumn{3}{|c|}{ PEG-Purified } & & & & \multirow[b]{2}{*}{ no. 1} & \multirow[b]{2}{*}{ no. 2} & \multirow[b]{2}{*}{ no. 3} \\
\hline & & no. 1 & no. 2 & no. 3 & no. 1 & no. 2 & no. 3 & no. 1 & no. 2 & no. 3 & & & \\
\hline \multirow{2}{*}{2} & Movement & + & - & + & $(+)$ & + & + & + & + & $(+)$ & + & + & + \\
\hline & Turbidity & - & - & - & - & - & - & - & - & - & - & - & - \\
\hline \multirow{2}{*}{27} & Movement & + & + & - & + & + & + & + & + & + & + & - & + \\
\hline & Turbidity & - & - & $(+)$ & - & - & - & - & - & - & - & - & - \\
\hline 49 & $\begin{array}{l}\text { Movement } \\
\text { Turbidity }\end{array}$ & $\begin{array}{c}+ \\
(+)\end{array}$ & $\begin{array}{c}+ \\
(+)\end{array}$ & $(+)$ & $\begin{array}{c}+ \\
(+)\end{array}$ & $\begin{array}{c}+ \\
(+)\end{array}$ & $\begin{array}{c}+ \\
(+)\end{array}$ & $\begin{array}{c}+ \\
(+)\end{array}$ & $\begin{array}{c}+ \\
(+)\end{array}$ & $\begin{array}{c}+ \\
(+)\end{array}$ & $\begin{array}{l}+ \\
-\end{array}$ & $\begin{array}{c}+ \\
(+)\end{array}$ & $\begin{array}{c}+ \\
(+)\end{array}$ \\
\hline 71 & $\begin{array}{l}\text { Movement } \\
\text { Turbidity }\end{array}$ & $\begin{array}{l}- \\
+\end{array}$ & $\begin{array}{c}- \\
(+)\end{array}$ & $\begin{array}{l}+ \\
-\end{array}$ & $\begin{array}{c}+ \\
(+)\end{array}$ & $\begin{array}{c}+ \\
(+)\end{array}$ & $\begin{array}{l}+ \\
(+)\end{array}$ & $\begin{array}{c}(+) \\
-\end{array}$ & $\begin{array}{c}+ \\
(+)\end{array}$ & $\begin{array}{c}+ \\
+ \\
(+)\end{array}$ & $\begin{array}{l}+ \\
-\end{array}$ & + & $\begin{array}{l}(+) \\
(+)\end{array}$ \\
\hline 144 & $\begin{array}{c}\text { Alive/Dead } \\
\text { Hatched or not }\end{array}$ & $\begin{array}{l}\text { Dead } \\
\text { Yes }\end{array}$ & $\begin{array}{l}\text { Dead } \\
\text { No }\end{array}$ & $\begin{array}{l}\text { Dead } \\
\text { No }\end{array}$ & $\begin{array}{l}\text { Alive } \\
\text { Yes }\end{array}$ & $\begin{array}{l}\text { Alive } \\
\text { Yes }\end{array}$ & $\begin{array}{l}\text { Dead } \\
\text { Yes }\end{array}$ & $\begin{array}{l}\text { Dead } \\
\text { Yes }\end{array}$ & $\begin{array}{l}\text { Dead } \\
\text { No }\end{array}$ & $\begin{array}{l}\text { Dead } \\
\text { Yes }\end{array}$ & $\begin{array}{l}\text { Dead } \\
\text { No }\end{array}$ & $\begin{array}{l}\text { Dead } \\
\text { Yes }\end{array}$ & $\begin{array}{l}\text { Alive } \\
\text { No }\end{array}$ \\
\hline \multicolumn{14}{|c|}{ (B) Phage bath exposure (Exp. II section B) } \\
\hline \multirow{3}{*}{$\begin{array}{l}\text { Time } \\
\text { (h) }\end{array}$} & \multirow{3}{*}{$\begin{array}{c}\text { Evaluated } \\
\text { Parameters }\end{array}$} & \multicolumn{6}{|c|}{ Crude lysate } & \multicolumn{6}{|c|}{ Control } \\
\hline & & \multicolumn{3}{|c|}{ FpV4 } & \multicolumn{3}{|c|}{ FPSV-D22 } & & & & & & \\
\hline & & no. 1 & no. 2 & no. 3 & no. 1 & no. 2 & no. 3 & & & & & & \\
\hline \multirow{2}{*}{0} & Movement & + & + & + & $(+)$ & $(+)$ & $(+)$ & \multicolumn{2}{|c|}{+} & \multicolumn{2}{|c|}{+} & \multicolumn{2}{|c|}{+} \\
\hline & Turbidity & - & - & - & - & - & - & \multicolumn{2}{|c|}{-} & & & \multicolumn{2}{|c|}{-} \\
\hline \multirow{2}{*}{24} & Movement & $(+)$ & $(+)$ & $(+)$ & + & $(+)$ & $(+)$ & & & & & & - \\
\hline & Turbidity & - & - & - & - & - & - & & & & & & \\
\hline & Movement & + & + & + & + & + & + & & & & & & \\
\hline 46 & Turbidity & - & - & - & - & - & - & & & & & & \\
\hline & Movement & + & $(+)$ & + & $(+)$ & + & + & & & & & & \\
\hline 68 & Turbidity & - & - & - & - & - & - & & & & & & $-)$ \\
\hline 144 & $\begin{array}{c}\text { Alive/Dead } \\
\text { Hatched or not }\end{array}$ & $\begin{array}{c}\text { Alive } \\
\text { No }\end{array}$ & $\begin{array}{l}\text { Alive } \\
\text { Yes }\end{array}$ & $\begin{array}{l}\text { Alive } \\
\text { Yes }\end{array}$ & $\begin{array}{c}\text { Alive } \\
\text { No }\end{array}$ & $\begin{array}{c}\text { Alive } \\
\text { Yes }\end{array}$ & $\begin{array}{l}\text { Dead } \\
\text { No }\end{array}$ & & & & & & $\begin{array}{l}\text { ive } \\
\text { es }\end{array}$ \\
\hline
\end{tabular}

+ Positive to movement or turbidity; (+) Weak movement/light turbidity; - Negative to movement or turbidity.

The concentration of FpV4 and FPSV-D22 associated with the eyed eggs was $8.2 \pm 0.7 \mathrm{PFU} \mathrm{mg}{ }^{-1}$ of egg and $3.9 \times 10^{2} \pm 1.3 \times 10^{1} \mathrm{PFU} \mathrm{mg}^{-1}$ of egg, respectively, at the end of the phage bath (Figure 4B). Subsequently, FpV4 phages were detected only after $24 \mathrm{~h}\left(0.9 \pm 1.1 \mathrm{PFU} \mathrm{m^{-1 }}\right.$ of egg $)$ as no phages were detected in the following samplings. On the contrary, even if the concentration of FPSV-D22 phages in connection with the eggs dropped in the first $24 \mathrm{~h}\left(0.1 \pm 0.1 \mathrm{PFU} \mathrm{mg}^{-1} \mathrm{of} \mathrm{egg}\right)$, it subsequently remained stable ( $46 \mathrm{~h}$ : $0.5 \pm 0.3$ PFU mg ${ }^{-1}$ of egg; $68 \mathrm{~h}: 0.3 \pm 0.1 \mathrm{PFU} \mathrm{mg}^{-1}$ of egg). Bacteriophage FpV4 and FPSV-D22 maintained relatively constant concentrations in the well content of the sampled eggs, ranging from $8.0 \times 10^{4} \pm 1.3 \times 10^{4} \mathrm{PFU} \mathrm{mL}^{-1}$ to $1.2 \times 10^{5} \pm 2.5 \times 10^{5} \mathrm{PFU} \mathrm{mL}^{-1}$ (FpV4) and from $1.4 \times 10^{5} \pm 1.3 \times 10^{4} \mathrm{PFU} \mathrm{mL}^{-1}$ to $1.7 \times 10^{4} \pm 1.3 \times 10^{4} \mathrm{PFU} \mathrm{mL}^{-1}$ (FPSV-D22) during the $144 \mathrm{~h}$ incubation (Figure 4B).

To summarize, in this experiment, we observed that the survival of the eyed eggs was not affected by the phage bath (crude lysates) and that the concentration of phages in connection with the eyed eggs decreased over time. While FpV4 phages disappeared after $24 \mathrm{~h}$, it was possible to detect FPSV-D22 phages until the last sampling (68 h). 


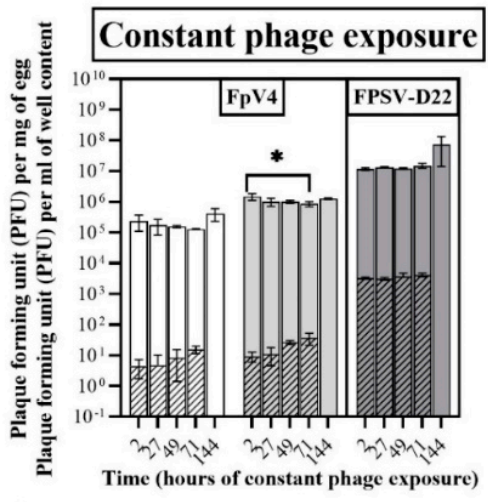

A

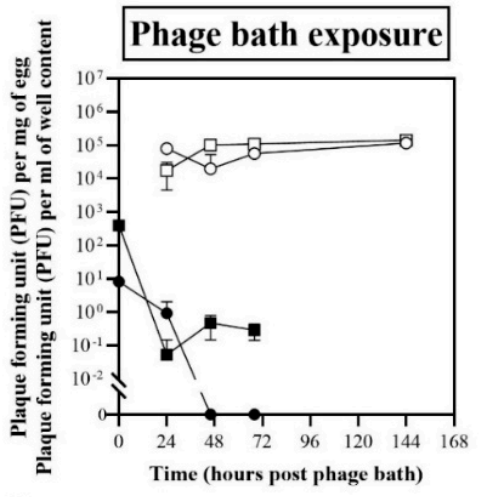

B

- FpV4

- FPSV-D22

Phages in the corresponding well conten

-O- FpV4

$-\square-$ FPSV-D22

Figure 4. Exp. I and II, section B: phages associated with the eyed eggs and in the corresponding well content (A) during constant exposure to phage FpV4 (crude lysate and PEG-purified solutions) and FPSV-D22 (PEG-purified solution) and (B) after a $4 \mathrm{~h}$ bath exposure to phage FpV4 and FPSV-D22 $\left(1.9 \times 10^{7} \mathrm{PFU} \mathrm{mL}{ }^{-1} \mathrm{FpV} 4\right.$ or $8.2 \times 10^{7} \mathrm{PFU} \mathrm{mL}^{-1}$ FPSV-D22; crude lysates). Values represent the mean and standard deviation of three biological replicates. At $144 \mathrm{~h}$, phages were quantified only for the well content. In $\mathbf{A},{ }^{*}=$ statistically significant differences between the concentration of phages detected at 2 and $71 \mathrm{~h}$ in connection with eyed eggs (adjusted $p=0.0184$ ) and in the corresponding well content (adjusted $p=0.0256$ ). No other statistically significant differences were detected between phage concentrations within each group (A).

\subsubsection{Bath and Constant Exposure of Eyed Eggs to F. columnare Phages (Exp. III, Section B)}

The surrounding medium influenced the survival of the eggs (data not shown). While all eggs had died after $96 \mathrm{~h}$ incubation in Shieh medium, only $16.67 \%$ mortality was observed in water, independent of the presence of phages.

Phages could not be isolated from bath-treated eggs despite the high phage titers in the surrounding liquid (Table 3). Only a few eggs were positive to FCL-2 and FCOVF27 with a concentration $\leq 10^{2} \mathrm{PFU} \mathrm{egg}^{-1}$. Both phages (FCL-2 and FCOV-F27) could be isolated from the corresponding well content (water/Shieh medium) from the bath, constant phage exposure, and phage control treatments at all the sampling points. The titers varied between $10^{5}-10^{9} \mathrm{PFU} \mathrm{mL}^{-1}$ depending on phage, time point, and treatment (Table 3). Shortly, both phages had somewhat higher titers in Shieh medium than in water, FCL-2 had higher titers than FCOV-F27, and constant treatments had higher titers than bath treatments. However, phages did not seem to attach efficiently to the eggs. 
Table 3. Exp. III, section B: F. columnare infecting phage titers in eggs and the surrounding medium (water or Shieh medium) at 0,24 , and $48 \mathrm{~h}$. Phage counts for two individual samples are provided for each treatment. A "+" indicates a positive detection of phages.

\begin{tabular}{|c|c|c|c|c|c|c|c|c|}
\hline \multicolumn{9}{|c|}{ (A) Exposure to Phage FCL-2 } \\
\hline \multirow{3}{*}{ Medium } & \multirow{3}{*}{ Sample } & \multirow{3}{*}{ Phage exposure } & \multicolumn{6}{|c|}{ Time (h) } \\
\hline & & & \multicolumn{2}{|c|}{0} & \multicolumn{2}{|c|}{24} & \multicolumn{2}{|c|}{48} \\
\hline & & & No. 1 & No. 2 & No. 1 & No. 2 & No. 1 & No. 2 \\
\hline \multirow{5}{*}{ WATER } & \multirow{3}{*}{$\begin{array}{c}\text { Well } \\
(\text { PFU ml m }\end{array}$} & Bath & $3.0 \times 10^{6}$ & $9.0 \times 10^{5}$ & $3.0 \times 10^{6}$ & $5.0 \times 10^{5}$ & $4.0 \times 10^{6}$ & $3.0 \times 10^{6}$ \\
\hline & & Constant & $9.0 \times 10^{7}$ & $1.0 \times 10^{9}$ & $9.0 \times 10^{6}$ & $1.0 \times 10^{9}$ & $3.0 \times 10^{7}$ & $2.5 \times 10^{7}$ \\
\hline & & Control (no egg) & $2.3 \times 10^{9}$ & $1.0 \times 10^{9}$ & $1.0 \times 10^{7}$ & $1.0 \times 10^{7}$ & $1.5 \times 10^{7}$ & $5.0 \times 10^{6}$ \\
\hline & \multirow{2}{*}{$\begin{array}{c}\text { Egg } \\
\left(\mathrm{PFU} \mathrm{egg}^{-1}\right)\end{array}$} & Bath & 0 & 0 & 0 & 0 & 0 & 0 \\
\hline & & Constant & 0 & $2.0 \times 10^{1}$ & $2.0 \times 10^{2}$ & 0 & $9.3 \times 10^{1}$ & $5.0 \times 10^{1}$ \\
\hline \multirow{5}{*}{ SHIEH } & \multirow{3}{*}{$\begin{array}{c}\text { Well } \\
\left(\text { PFU ml }{ }^{-1}\right)\end{array}$} & Bath & $8.0 \times 10^{6}$ & $7.0 \times 10^{7}$ & $2.0 \times 10^{8}$ & $1.0 \times 10^{7}$ & $9.0 \times 10^{6}$ & $7.0 \times 10^{7}$ \\
\hline & & Constant & $3.5 \times 10^{9}$ & $2.0 \times 10^{9}$ & $8.0 \times 10^{9}$ & $2.0 \times 10^{9}$ & $4.5 \times 10^{9}$ & $5.5 \times 10^{9}$ \\
\hline & & Control (no egg) & $3.5 \times 10^{9}$ & $2.0 \times 10^{9}$ & $3.5 \times 10^{9}$ & $4.0 \times 10^{9}$ & $2.0 \times 10^{9}$ & $8.0 \times 10^{8}$ \\
\hline & \multirow{2}{*}{$\begin{array}{c}\text { Egg } \\
\left(\mathrm{PFU} \mathrm{egg}^{-1}\right)\end{array}$} & Bath & 0 & 0 & 0 & 0 & 0 & 0 \\
\hline & & Constant & 0 & 0 & 0 & 0 & 0 & 0 \\
\hline \multicolumn{9}{|c|}{ (B) Exposure to Phage FCOV-F27 } \\
\hline \multirow{3}{*}{ Medium } & \multirow{3}{*}{ Sample } & \multirow{3}{*}{ Phage exposure } & \multicolumn{6}{|c|}{ Time (h) } \\
\hline & & & \multicolumn{2}{|c|}{0} & \multicolumn{2}{|c|}{24} & \multicolumn{2}{|c|}{48} \\
\hline & & & No. 1 & No. 2 & No. 1 & No. 2 & No. 1 & No. 2 \\
\hline \multirow{5}{*}{ WATER } & \multirow{3}{*}{$\begin{array}{c}\text { Well } \\
\left(\text { PFU ml }{ }^{-1}\right)\end{array}$} & Bath & $1.5 \times 10^{5}$ & $1.0 \times 10^{5}$ & + & + & + & $4.0 \times 10^{5}$ \\
\hline & & Constant & $1.3 \times 10^{7}$ & $5.0 \times 10^{6}$ & $3.0 \times 10^{6}$ & $2.0 \times 10^{6}$ & + & $2.0 \times 10^{6}$ \\
\hline & & Control (no egg) & $1.5 \times 10^{7}$ & $2.1 \times 10^{7}$ & + & $3.0 \times 10^{6}$ & $1.8 \times 10^{7}$ & + \\
\hline & \multirow{2}{*}{$\begin{array}{c}\text { Egg } \\
\left(\mathrm{PFU} \mathrm{egg}^{-1}\right)\end{array}$} & Bath & 0 & 0 & 0 & 0 & 0 & 0 \\
\hline & & Constant & $2.3 \times 10^{2}$ & 0 & $5.0 \times 10^{0}$ & 0 & 0 & 0 \\
\hline \multirow{5}{*}{ SHIEH } & \multirow{3}{*}{$\begin{array}{c}\text { Well } \\
(\text { PFU ml } \\
-1)\end{array}$} & Bath & $2.0 \times 10^{6}$ & $1.0 \times 10^{6}$ & $6.0 \times 10^{6}$ & $7.0 \times 10^{6}$ & $2.0 \times 10^{7}$ & $1.0 \times 10^{7}$ \\
\hline & & Constant & $4.5 \times 10^{9}$ & $1.0 \times 10^{9}$ & $2.0 \times 10^{9}$ & $8.0 \times 10^{8}$ & $1.5 \times 10^{9}$ & $9.0 \times 10^{8}$ \\
\hline & & Control (no egg) & $6.0 \times 10^{8}$ & $5.0 \times 10^{8}$ & $2.0 \times 10^{9}$ & $8.0 \times 10^{8}$ & $3.0 \times 10^{9}$ & $2.0 \times 10^{9}$ \\
\hline & Egg & Bath & 0 & 0 & 0 & 0 & 0 & 0 \\
\hline & $\left(\mathrm{PFU} \mathrm{egg}^{-1}\right)$ & Constant & 0 & 0 & 0 & 0 & 0 & 0 \\
\hline
\end{tabular}

\subsection{Experiments to Evaluate the Use of Phages as Control Agents (Section C)}

\subsubsection{Phage Bath of F. psychrophilum Challenged Eggs (Exp. I, Section C)}

After the bacterial challenge with either F. psychrophilum 950106-1/1 or the strain 160401/1-5N (sterile TYES-B for the control), eyed eggs were bath-exposed to phages FpV4 and FPSV-D22 (mixed 1:1) for $48 \mathrm{~h}$. Two control baths were included: one containing SM buffer (the buffer where the phages were purified in) and the other with Milli-Q water (to evaluate the effect of the buffer). Subsequently, eyed eggs were moved to 24-well sterile plates containing sterile Milli- $Q$ water (experimental set up in Figure A1). The results of this experiment are presented in Figures 5-7. The time point at which the bacterial bath challenge was finalized is named as $0 \mathrm{~h}$ post infection (hpi). 

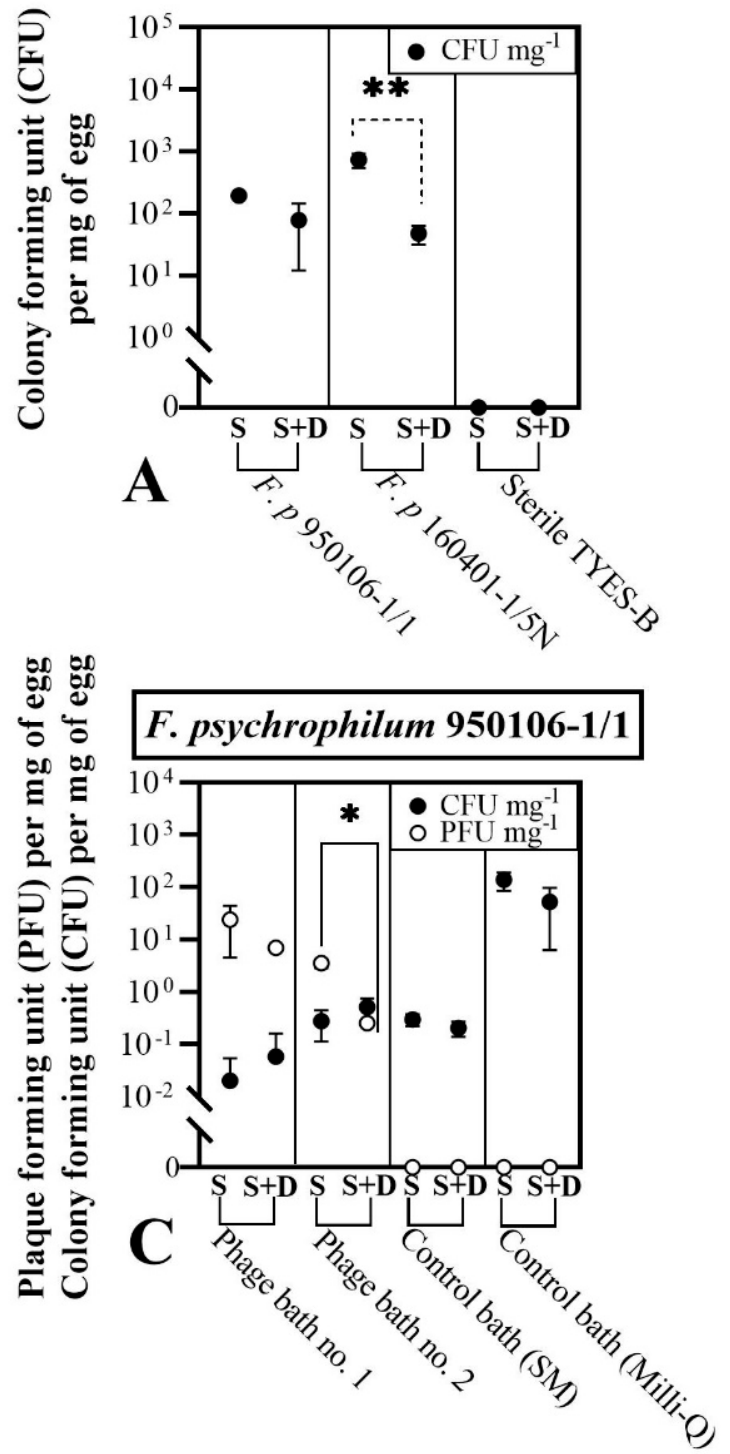

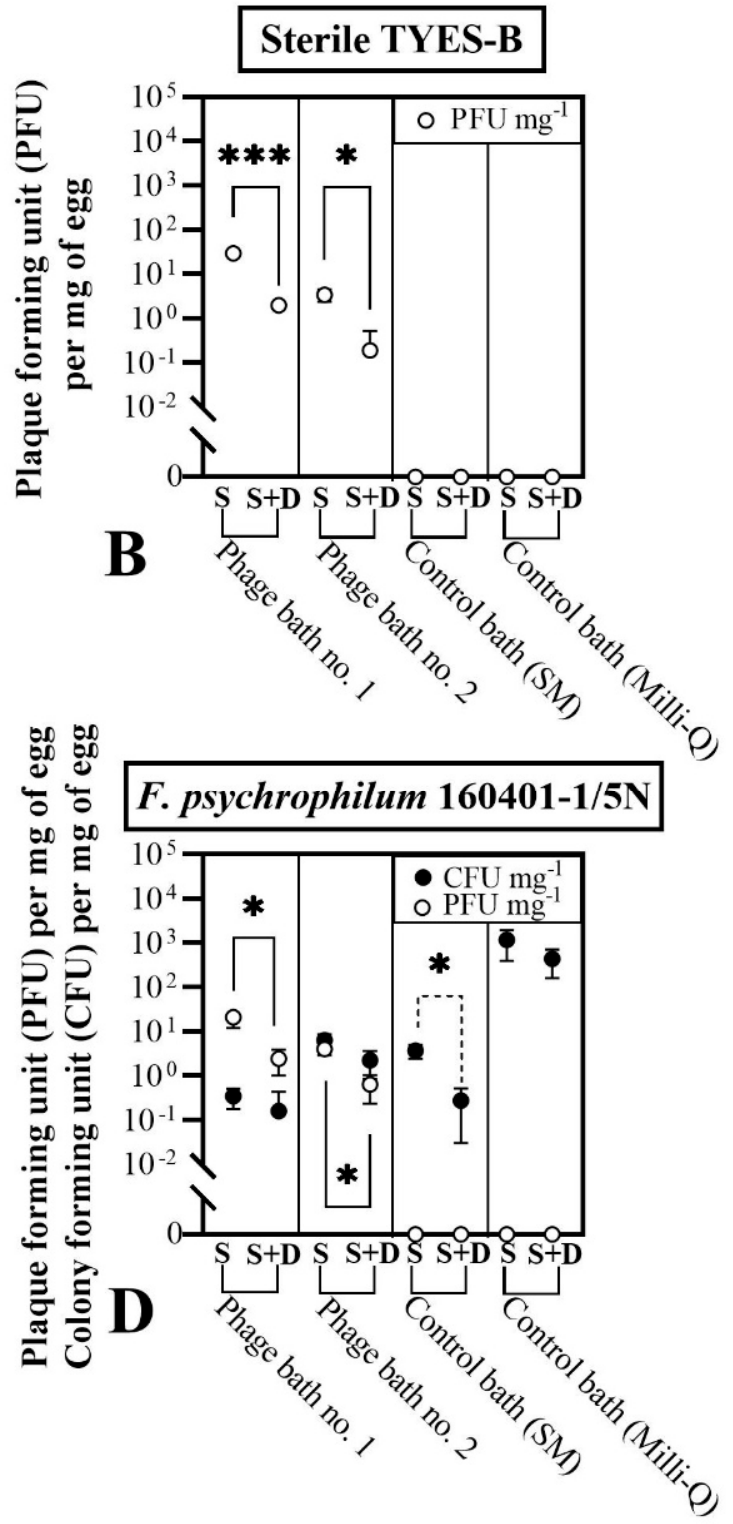

Figure 5. Exp. I, section C: effects of the drying procedure on bacterial and phage concentrations in connection with eyed eggs. Comparison between standard sampling (indicated by " $\mathrm{S}$ ") and sampling with the additional drying step (indicated by "S + D") for eyed eggs sampled at 0 hpi (A, right after the bath challenge) and at 24 hpi (B-D) that were previously bath-challenged with TYES-B (control, B), F. psychrophilum 950106-1/1 (C) and F. psychrophilum 160401-1/5N (D). Values represent the mean and standard deviation of three biological replicates. Unpaired $t$ tests of log-transformed values were performed. Statistically significant comparisons (solid lines for phage concentrations and broken lines for bacteria concentrations) are visualized as follows: $p<0.05\left(^{*}\right), p<0.001\left(^{* *}\right), p<0.0001\left(^{* * *}\right)$. Phage bath no. 1: $10^{9} \mathrm{PFU} \mathrm{mL}^{-1}$; phage bath no. 2: $10^{8}$ PFU $\mathrm{mL}^{-1}$. 

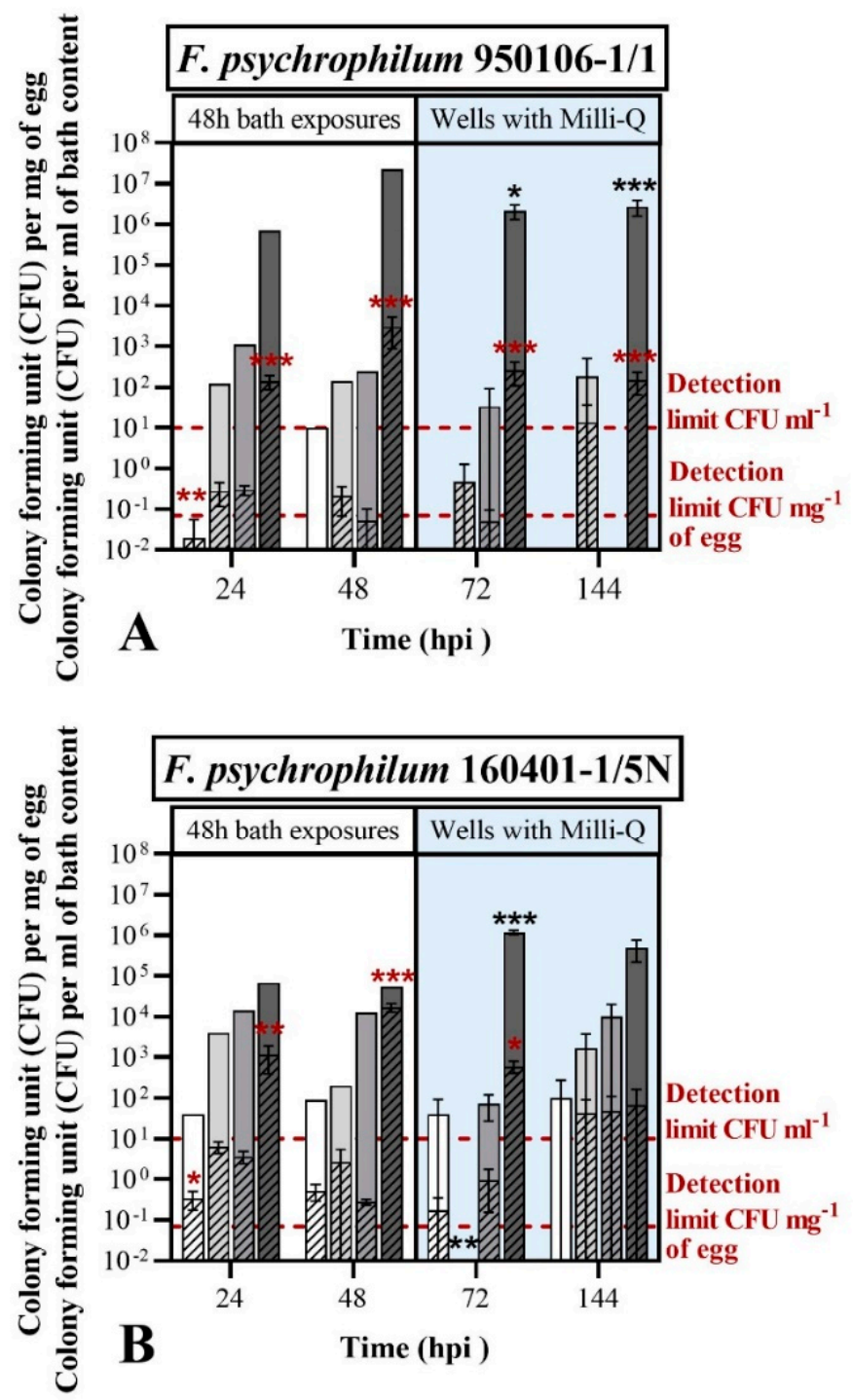

Bacteria in the corresponding bath/wells

$\square$ Phage bath no. 1

$\square$ Phage bath no. 2

$\square$ Control bath (SM buffer)

$\square$ Control bath (Milli-Q water)

\section{Bacteria in connection with eyed eggs}

mas Phage bath no. 1

एय] Phage bath no. 2

שID Control bath (SM buffer)

m Control bath (Milli-Q water)

Figure 6. Exp. I, section C: F. psychrophilum 950106-1/1 (A) and F. psychrophilum 160401-1/5N (B) in connection with the eyed eggs and in the corresponding bath/well. After the bacterial challenge, eyed eggs were bath-exposed to phages FpV4 and FPSV-D22 mixed 1:1 (phage bath no. 1: $10^{9} \mathrm{PFU} \mathrm{mL}^{-1}$; phage bath no. 2: $10^{8}$ PFU $\mathrm{mL}^{-1}$; or control baths containing either SM buffer or Milli-Q water) for $48 \mathrm{~h}$ and subsequently moved to 24-well sterile plates containing sterile Milli-Q water (in light blue). Values represent the mean and standard deviation of three biological replicates except for the bath content at 24 and 48 hpi $(n=1)$. In the control group for bacterial infection (control bath with TYES-B), F. psychrophilum was not detected in eyed eggs and in the corresponding bath/wells. For the concentration of bacteria, the detection limit is indicated by red broken lines (calculated as $1 \mathrm{CFU}$ was observed in the undiluted egg (mean weight $=100 \mathrm{mg}$ ) or well sample). Unpaired $\mathrm{t}$ tests of log-transformed values were performed to compare the tested conditions (phage baths and Milli-Q water-control bath) with the SM buffer-control bath. Statistically significant comparisons are visualized on top of each column (red: eyed egg values; black: well values) as follows: $p<0.05\left(^{*}\right)$, $p<0.001{ }^{(* *)}, p=0.0001{ }^{(* *)}$. 

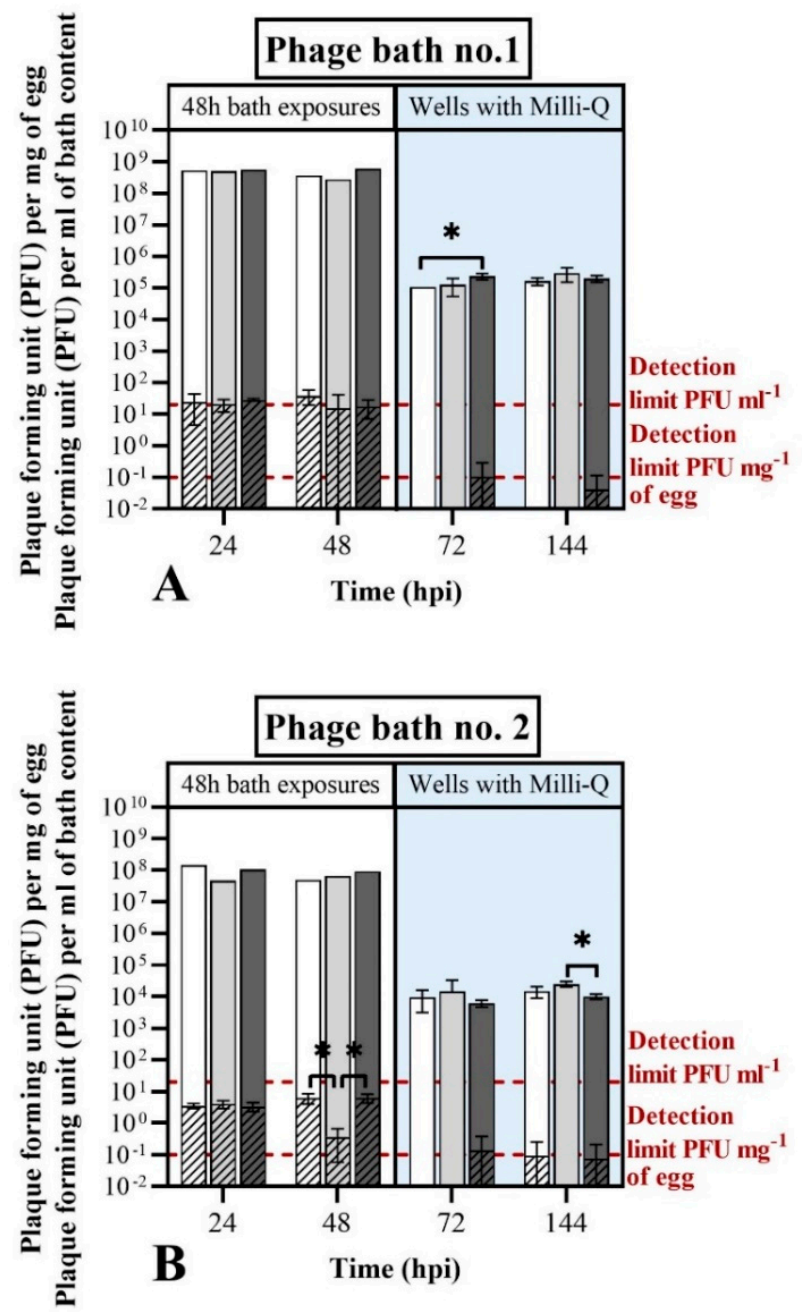

Phages in the corresponding bath/wells

$\square+F$. psychrophilum 950106-1/1

$\square+F$.psychrophilum $160401-1 / 5 \mathrm{~N}$

- F.psychrophilum

\section{Phages in connection with eyed eggs}

wa +F.psychrophilum 950106-1/1

mas + F.psychrophilum 160401-1/5N

ma - F. psychrophilum

Figure 7. Exp. I, section C: phages FpV4 and FPSV-D22 in connection with the eyed eggs and in the corresponding bath/well following phage bath exposures: (A) phage bath no. $1\left(10^{9} \mathrm{PFU} \mathrm{mL} \mathrm{mL}^{-1}\right)$ and (B) phage bath no. $2\left(10^{8} \mathrm{PFU} \mathrm{mL}^{-1}\right)$. In the phage bath control groups (containing either SM buffer or Milli-Q water), phages FpV4 and FPSV-D22 were not detected. After the bacterial challenge, eyed eggs were bath-exposed to phages FpV4 and FPSV-D22 for $48 \mathrm{~h}$ and subsequently moved to 24-well sterile plates containing sterile Milli-Q water (in light blue). Values represent the mean and standard deviation of three biological replicates, except for the bath content at 24 and 48 hpi $(n=1)$. For the concentration of phages, the detection limit is indicated by red broken lines (calculated as 1 PFU was observed in only one of the triplicate spots in the undiluted egg (mean weight $=100 \mathrm{mg}$ ) or well sample). Unpaired t tests of log-transformed values were performed to compare the tested conditions. Statistically significant comparisons are indicated as follows: $p<0.05\left(^{*}\right), p<0.001\left({ }^{* *}\right), p=0.0001$ ${ }^{* * *}$. F. psychrophilum 950106-1/1 and the strain 160401-1/5N were used as bacterial hosts for the phage quantification analysis according to which strain was used in the bacterial bath challenge.

The first objective of this experiment was to study the association of phages and bacteria with the surface of the eyed eggs. Thus we compared the number of bacteria and phages per mg of egg at 0 and $24 \mathrm{hpi}$, sampled with either the standard procedure $(S)$ or including a drying step $(S+D)$, to assess to what extent the bacterial cells and 
the phages were firmly attached to the egg surface or associated with the liquid around the eggs (Figure 2 step 2). The results are presented in Figure 5. When the eyed eggs were bath-challenged with F. psychrophilum 950106-1/1, $1.9 \times 10^{2} \pm 3.2 \times 10^{1} \mathrm{CFU} \mathrm{mg}^{-1}$ of egg was found using the standard procedure (S) at $0 \mathrm{hpi}$, and no significant loss of bacteria by the drying procedure was observed ( + D: $7.7 \times 10^{1} \pm 6.5 \times 10^{1} \mathrm{CFU} \mathrm{mg}{ }^{-1}$ of egg; $p=0.0902$ ) (Figure 5A). This was also observed at $24 \mathrm{hpi}$ (Figure 5C). The bacterial concentrations were $0.3 \pm 0.1$ and $1.4 \times 10^{2} \pm 5.4 \times 10^{1} \mathrm{CFU} \mathrm{mg}{ }^{-1}$ of egg in SM buffer and Milli-Q water, respectively, but with no significant difference between the $S$ and $S+D$ treatments. Exposure of the F. psychrophilum 950106-1/1-challenged eggs to phages did not influence the effects of the drying step on bacterial abundance.

The concentration of F. psychrophilum 160401-1/5N, on the other hand, seemed to be more affected by the inclusion of the drying step, as a 10-fold decrease after drying was detected at 0 hpi (S: $7.3 \times 10^{2} \pm 2.0 \times 10^{2} \mathrm{CFU} \mathrm{mg}{ }^{-1}$ of egg; $\mathrm{S}+\mathrm{D}: 7.7 \times 10^{1} \pm 1.6 \times 10^{1} \mathrm{CFU} \mathrm{mg}^{-1}$ of egg; $p=0.0004$ ) (Figure 5A). A similar effect was observed at 24 hpi when the eyed eggs were placed in SM buffer (S: $3.6 \pm 1.2 \mathrm{CFU} \mathrm{mg}{ }^{-1}$ of egg; S + D: $0.3 \pm 0.2 \mathrm{CFU} \mathrm{mg}{ }^{-1}$ of egg; $p=0.0056$ ), but no significant changes were observed in the other groups (Figure 5D). Overall, these findings show that a fraction of the two selected F. psychrophilum strains was tightly attached to the eyed eggs' surface and was not detached by the drying step. Additionally, there was a general decrease in egg-associated bacteria over $24 \mathrm{~h}$ incubations, even in the SM buffer control groups.

Phages seemed to be less closely attached to the surface of the eyed eggs. The inclusion of the drying step caused a 10- to a 100-fold decrease in phage concentrations in connection with the eyed eggs in each of the tested cases, independent of the presence of the bacteria (Figure 5B-D). For example, the number of phages recorded at $24 \mathrm{hpi}$ in connection with the eyed eggs not exposed to F. psychrophilum (sterile TYES-B; Figure 5B) was $2.9 \times 10^{1} \pm 2.6 \mathrm{PFU} \mathrm{mg}{ }^{-1}$ of egg for the $S$ procedure compared to $0.7 \pm 0.2 \mathrm{PFU} \mathrm{mg}{ }^{-1}$ of egg for the $\mathrm{S}+\mathrm{D}$ procedure $(p<0.0001)$ for eggs bathed in phage bath no. $1\left(10^{9} \mathrm{PFU} \mathrm{mL}^{-1}\right)$, and $1.4 \pm 0.4 \mathrm{PFU} \mathrm{mg} \mathrm{m}^{-1}$ of egg for the $S$ procedure compared to $0.1 \pm 0.1 \mathrm{PFU} \mathrm{mg} \mathrm{m}^{-1}$ of egg for the $S+D$ procedure $(p<0.05)$ for eggs bathed in phage bath no. $2\left(10^{8} \mathrm{PFU} \mathrm{mL}^{-1}\right)$.

To evaluate the ability of phages to control F. psychrophilum, the bacterial and phage concentrations in connection with the eyed eggs were measured with the standard sampling procedure (S). Bacteria and phages were quantified on eggs sampled during the phage exposure in the bath treatment (at 24 and $48 \mathrm{hpi}$ ) and during the subsequent incubation in wells (at 72 and $144 \mathrm{hpi}$ ) (Figures 6 and 7). No negative effect on the eyed eggs' survival was observed in any of the groups, as all the eyed eggs sampled at 24, 48, 72, and $144 \mathrm{hpi}$ were characterized as alive based on movement and turbidity indicators (Figure A3).

The concentration of bacteria per mg of egg was significantly reduced at $24 \mathrm{hpi}$ in the case of phage bath exposure no. $1\left(10^{9} \mathrm{PFU} \mathrm{mL}{ }^{-1}\right)$ in comparison to the control bath (SM buffer) (Figure 6). In fact, for bath-challenged eyed eggs with F. psychrophilum 950106-1/1, the concentration of bacteria associated with the eggs at $24 \mathrm{hpi}$ was $0.02 \pm 0.04 \mathrm{CFU} \mathrm{mg}{ }^{-1}$ of egg in the phage bath exposure no. 1, compared with $0.3 \pm 0.1 \mathrm{CFU} \mathrm{mg}{ }^{-1}$ of egg in the case of the SM buffer-bath control $(p<0.001)$, corresponding to a 15-fold reduction in egg-associated bacteria due to the phage treatment (Figure 6A). A similar effect of phage exposure was observed for F. psychrophilum 160401-1/5N at 24 hpi, where egg-associated bacteria were reduced from $3.6 \pm 1.2 \mathrm{CFU} \mathrm{mg}{ }^{-1}$ of egg in the SM buffer-bath control to $0.3 \pm 0.2 \mathrm{CFU} \mathrm{mg}{ }^{-1}$ of egg in the phage bath exposure no. $1(p=0.0022$, Figure $6 \mathrm{~B})$.

Additionally, phage exposure reduced the bacterial abundance at $24 \mathrm{hpi}$ in the bath content for both bacteria (Figure 6A,B). For F. psychrophilum 950106-1/1 no bacteria was detected in the phage bath no. 1 at $24 \mathrm{hpi}$, whereas $1.1 \times 10^{3} \mathrm{CFU} \mathrm{mL} \mathrm{m}^{-1}$ $(n=1)$ were present in the SM buffer-bath control (Figure 6A). Similarly, the abundance of strain $160401-1 / 5 \mathrm{~N}$ was reduced from $1.4 \times 10^{4} \mathrm{CFU} \mathrm{mL}^{-1}$ in the SM buffer-bath control to $40.0 \mathrm{CFU} \mathrm{mL} \mathrm{m}^{-1}$ in phage bath no. $1(n=1$, Figure $6 \mathrm{~B})$. These findings support the ability of FpV4 and FPSV-D22 to reduce the F. psychrophilum abundance at $24 \mathrm{hpi}$ both on the egg surface and in the surrounding water. However, this effect of phage 
exposure was only temporary, as no significant difference between the bacterial abundances of the phage baths and the SM buffer-bath controls were observed at the following time points $(48,72$, and $144 \mathrm{hpi})$. In addition, the growth and stability of the bacteria seemed to be increasingly negatively affected by incubation in the SM buffer-control bath compared to the Milli-Q water-control bath over time. As an example, at $72 \mathrm{hpi}$, the bacterial abundances detected in connection with the eyed eggs was $0.1 \pm 0.1$ and $2.6 \times 10^{2} \pm 1.5 \times 10^{2} \mathrm{CFU} \mathrm{mg}{ }^{-1}$ of egg for eyed eggs previously bathed in SM buffer and Milli-Q water, respectively, $(p<0.0001)$ (bath-challenged eyed eggs with F. psychrophilum 950106-1/1). The bacterial concentration in the corresponding wells containing the eggs was also significantly decreased (SM buffer bath-control: $3.3 \times 10^{1} \pm 5.8 \times 10^{1} \mathrm{CFU} \mathrm{mL}^{-1}$; Milli-Q water-control bath: $\left.2.1 \times 10^{6} \pm 8.4 \times 10^{5} \mathrm{CFU} \mathrm{mL} \mathrm{mL}^{-1} ; p<0.05\right)$. A similar trend was observed for bath-challenged eyed eggs with F. psychrophilum 160401-1/5N at 72 hpi (bacte-

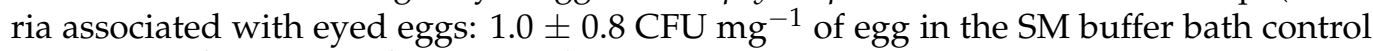
and $6.0 \times 10^{2} \pm 2.0 \times 10^{2} \mathrm{CFU} \mathrm{mg}{ }^{-1}$ of egg in the Milli-Q water control bath $-p=0.0027$ ). This was also the case in the corresponding wells where $7.3 \times 10^{1} \pm 4.6 \times 10^{1} \mathrm{CFU} \mathrm{mL}^{-1}$ were found in the SM buffer bath control compared to $1.2 \times 10^{6} \pm 1.4 \times 10^{5} \mathrm{CFU} \mathrm{mL}^{-1}$ in the Milli-Q water control bath $(p<0.0001)$. The detection of bacteria/fungi other than F. psychrophilum was observed during the CFU enumeration and recorded (Figure A4).

The concentration of the two bacterial strains associated with the bath-challenged eyed eggs at 24 and $48 \mathrm{hpi}$ in the Milli-Q water-control bath varied significantly with F. psychrophilum 950106-1/1, occurring in 10-fold lower numbers $\left(1.4 \times 10^{2} \pm 5.4 \times 10^{1}\right.$ and $3.1 \times 10^{3} \pm 2.2 \times 10^{3} \mathrm{CFU} \mathrm{mg}{ }^{-1}$ of egg at $24 \mathrm{hpi}$ and $48 \mathrm{hpi}$, respectively) than strain $160401-1 / 5 \mathrm{~N}\left(1.2 \times 10^{3} \pm 7.8 \times 10^{2}\right.$ and $1.7 \times 10^{4} \pm 4.0 \times 10^{3} \mathrm{CFU} \mathrm{mg}{ }^{-1}$ of egg at 24 and 48 hpi, respectively) (24 hpi: $p=0.0030 ; 48$ hpi: $p=0.0080)$, suggesting different adherence properties of the two strains (Figure 6).

As previously observed and mentioned in this results section (Figure 5), the phages FpV4 and FPSV-D22 did not seem to tightly connect with surface of the eyed eggs in this experiment. Even if the concentration of phages in connection with the eyed eggs was $\sim 10^{1} \mathrm{PFU} \mathrm{mg}{ }^{-1}$ (Phage bath no. 1 ) and $\sim 10^{0} \mathrm{PFU} \mathrm{mg}{ }^{-1}$ (phage bath no. 2) during the $48 \mathrm{~h}$ phage bath, very few eggs were positive to phages in the next sampling points (72 and 144 hpi) (Figure 7). However, FpV4 and FPSV-D22 were constantly detected over time, and their concentration was maintained in the baths and the wells, independent of the presence of the bacteria.

To summarize, the findings of this experiment showed that the two selected F. psychrophilum strains closely interact with the eyed eggs' surface, but with different efficiencies. Furthermore, exposure of the challenged eggs to phages showed a 12- to 15-fold reduction in egg-associated bacteria for $24 \mathrm{~h}$. However, the growth and stability of the bacteria were negatively affected in the SM buffer bath at all the time points, and the controlling effects of phages on the egg-associated bacteria were not maintained beyond $24 \mathrm{~h}$.

\subsubsection{Phage Exposure of F. columnare Challenged Eggs (Exp. II, Section C)}

The effects of phages on bacteria associated with eggs and their immediate proximity was also assessed with F. columnare (experimental set up in Figure A2). As for F. psychrophilum, most of the eggs survived until the end of the experiments (Figure S2). Some eggs hatched during the experiment.

In contrast to the experiments in section A (Figure S1), F. columnare was not isolated from any of the medium or egg samples taken at any sampling time point. It can thus be inferred that there was no growing or infective F. columnare in the treatments during the experiment, probably since the experiment was conducted at $10^{\circ} \mathrm{C}$. However, colonies of other environmental bacteria were observed (data not shown).

Phages were only isolated from egg samples in low titers right after phage bath exposure experiment (Figure 8). One should notice that, in this experiment, eggs were not homogenized as in the previous experiments, but only vortexed in a fixed amount of water, which was then used for the phage and bacterial quantifications. Phages were isolated 
from well samples $(n=3)$ during constant phage exposure at all sampling points with a stable concentration, independent of the presence of F. columnare (e.g., $48 \mathrm{~h}$ in the case of the bacterial challenge: $\left.9.3 \times 10^{4} \pm 7.8 \times 10^{4} \mathrm{PFU} \mathrm{mL}{ }^{-1}\right)$. After the phage bath, it was possible to detect phages at 0 and $48 \mathrm{~h}$ in only one of the three wells.
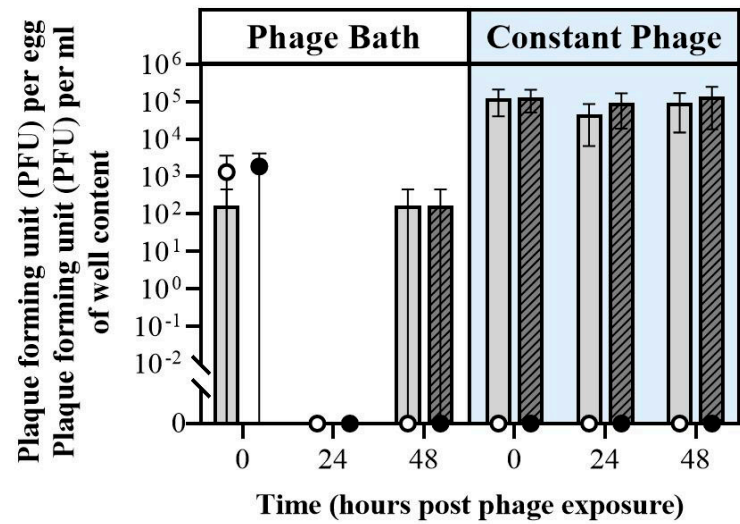

Phages in the corresponding wells

$\square+F$. columnare

W - F. columnare

Phages in connection with eyed eggs

- $+F$. columnare

- - F. columnare

Figure 8. Exp. II, section C: phage FCL-2 in connection with the eyed eggs and in the corresponding wells following phage exposures (bath and constant) with and without bacterial challenge. In the phage control groups (sterile $\mathrm{NaCl} 0.09 \%$; bath and constant experiments), phage FCL-2 was detected neither in the wells nor in the egg samples. Values represent the mean and standard deviation of three biological replicates. Unpaired $t$ tests of log-transformed values were performed to compare the observed phage titers in the wells with and without bacterial exposure (constant phage exposure). No statistically significant difference was detected $(p>0.05)$.

\section{Discussion}

Our study aimed to evaluate the interactions between Flavobacterium spp. and rainbow trout eyed eggs and the potential of phages as control agents for these pathogens.

\subsection{Experimental Infection Method}

Although distant from the hatchery environment, the developed experimental set up allows for the study of bacterial and phage interactions with eyed eggs at a small scale under controlled conditions, as well as the production of reproducible results, meaning that the experimental set up might also be applied for other pathogenic bacteria.

No evident negative effects on survival were detected when eyed eggs were exposed to F. psychrophilum in our experiments (Section A and C), supporting previous findings of [46], in which no egg mortality was observed prior to hatching in the bacteria-challenged rainbow trout eyed eggs. However, the mortality of post-swim up fry exposed to F. psychrophilum was significantly higher than the controls in that study [46]. A different infection method was chosen by Ekman et al. [47], where the nano-injection of F. psychrophilum into the yolk of fertilized rainbow trout eggs was performed with the aim of mimicking the vertical transmission of this pathogen. In this study, significantly higher mortality rates were observed for the eggs exposed to the pathogen compared to the controls. However, this method bypasses the immune adaptive response (which is in a stage of development) and the physical barriers of the eyed egg (chorion and membranes). In addition, the vertical transmission and the intra ovum presence of this bacterium in rainbow trout has not been clearly demonstrated [11,48].

F. psychrophilum did not grow actively in water, but its concentration remained stable up to 13 days after inoculation (Figure 3B). This was in agreement with previous studies $[49,50]$, where the concentration of F. psychrophilum in stream water and sterilized natural freshwater (measured by CFU count) remained stable for 116 days [49] and for 300 days [50], respectively. However, an initial drop in the bacterial concentration was detected in [50]. In [49], the authors observed that the number of viable bacterial cells was 
higher (viable but non-culturable; measured by a viability assay) than the one enumerated with CFU count, suggesting that $F$. psychrophilum may undergo a starvation phase. Even after 9 months, cells were resuscitated in Cytophaga broth, regaining their initial morphology [49]. Similar observations have been recorded for F. columnare [51].

Experiments with eggs and F. columnare showed that the presence of nutrients (Shieh medium) had an adverse effect on egg survival, and maybe more importantly, that their optimum temperature does not match. While F. columnare grows well in high (above $+18^{\circ} \mathrm{C}$ ) temperatures, this is not a suitable temperature for egg viability (the incubation of eyed eggs at temperatures higher than $12{ }^{\circ} \mathrm{C}$ can cause the development of skeletal deformities [52]). It is thus unlikely that $F$. columnare would cause problems in rainbow trout eyed eggs. However, different bacterial strains may have the ability to also grow at these lower temperatures [44], therefore the interactions between F. columnare and rainbow trout eggs might occur [53]. Furthermore, since this pathogen is also present in warm countries and tropical fish [54,55], and F. columnare has been previously found in association with Chinook salmon eggs [56], it remains relevant to study the association of bacteria and their phages in fish eggs. Indeed, F. columnare was isolated from all treatments (Figure S1), suggesting potential interactions in the hatchery conditions where conditions favor the presence of this bacterium.

Growth of bacteria/fungi other than the one of interest was detected (section A,B and C) and it was more prominent in experiments performed during late spring (including not published data), suggesting seasonal changes in the microbial community surrounding the chorion of the eyed eggs [57]. In addition, the lysis of bacterial cells caused by the phages releases nutrients and may stimulate the growth of other bacteria, as suggested by [58]. However, bacterial growth other than F. psychrophilum was detected independently of phage presence in the case of bacteria-challenged eggs (Exp. I section C, Figure 4B). Less detection of bacteria other than F. psychrophilum was observed in the control group for the bacterial infection. It is known that the iodine disinfection, a standard disinfection method for salmonid eyed eggs in hatcheries, does not create a sterile environment [56,59]. However, the use of higher iodine concentrations than the ones used are not recommended since this may compromise the survival of the eggs after the treatment. The growth of a background bacterial community was previously observed in phage studies in challenge experiments with Vibrio spp. and fish larvae [58,60]. Here, a positive effect of phages on the survival of Vibrio-challenged turbot and cod larvae were detected, despite a relatively high mortality caused by the background larval-associated bacterial community [36]. In our experiments, a correlation between higher mortality and the detection of other bacteria was not observed.

It is important to be aware that our experimental approach is only valid for short-term disinfection efficiency experiments, and does not consider the effects on overall survival or the hatching rate of the eyed eggs, and other factors, e.g., oxygen requirements (in salmonid eggs the hatching of the eggs happens faster in conditions of asphyxia) [61], may be influencing these parameters.

\subsection{Rainbow Trout Eyed Eggs-Bacteriophage Interactions}

The virulent phages FpV4 and FPSV-D22 targeting F. psychrophilum do not seem to affect the survival of rainbow trout eyed eggs (Table 2), as rainbow trout eyed eggs could tolerate the presence of bacteriophages under the tested conditions. These effects were observed for up to $71 \mathrm{~h}$ when phages were diluted in TYES medium (Exp. I section B), and up to $144 \mathrm{~h}$ when in Milli-Q water (Exp. II section B), and thus indicated that phage applications for F. psychrophilum control do not have a negative impact on egg survival for the tested time period. Similar results were obtained by Silva et al. [60], where the exposure of zebrafish larvae to Vibrio phages did not negatively affect the survival of the larvae. However, the embryo movement was not observed for a higher number of eyed eggs exposed to the phage FpV4 in crude lysate compared to the other groups (Exp. I 
section B), suggesting that PEG-purified solutions should be chosen over crude lysates for long-term exposures.

The qualitative and quantitative analysis of phages showed that it was possible to detect FpV4 and FPSV-D22 associated with eyed eggs after both constant (Exp. I section B) and short-term bath exposure (Exp. II section B). While the concentration of phages associated with the eggs was maintained over time during constant exposure (Figure 4A), it decreased after $24 \mathrm{~h}$ post-phage bath (Figure $4 \mathrm{~B}$ ) suggesting that phages do not tightly interact with the surface of the eggs. In particular, while a significant increase in the phage FpV4 concentration was detected during constant PEG-purified phage exposure, FpV4 in connection with eyed eggs was detected at very low titers $24 \mathrm{~h}$ after the phage bath, and could not be detected in the following samplings. The concentration of phages in the surrounding medium was constant. In contrast, FPSV-D22 in connection with the eyed eggs was detected for a longer period after the bath procedure and in a higher concentration compared to FpV4 during constant exposure experiments. These differences likely reflect differences in adherence and stability of the two phages during the interactions with the egg membranes. FpV4 belongs to the Podoviridae family with very short tails, whereas FPSV-D22 is a Siphoviridae $[27,36,62]$ with long flexible tails, and these differences in phage morphology may affect their adherence to biotic surfaces. In addition, the time of exposure seems to represent an important variable.

Similar results were obtained with phages infecting F. columnare (FCL-2 and FCOVF27): phages were detected from eggs at very low titer, while maintaining high concentrations in the surrounding medium. Further investigations are needed to shed light on this matter. Indeed, the binding of $F$. columnare phages on mucins found in mucosal surfaces have provided promising results for phage-based bacterial control and prophylaxis [63]. However, it is unclear if similar mucin glycoproteins are present on egg surfaces, which also is distinct to the mucosal secretion of fish skin. Therefore, the phages may not strictly bind to the chorion, but rather survive in the surrounding environment. Nevertheless, the presence of pathogen-targeting phages in the proximity of the eggs may prevent the bacterial infection after hatching.

\subsection{Phages as Control Agents for F. psychrophilum in Eyed Eggs}

The combined action of FpV4 and FPSV-D22 demonstrated the ability to reduce the number of bacteria associated with the eyed eggs and contained in the corresponding bath/well during the first 24 hpi (Figure 6, Phage bath no. 1: $10^{9} \mathrm{PFU} \mathrm{mL}{ }^{-1}$ ). However, this controlling effect of the phages was only temporary, and the observed negative effect of the SM buffer on F. psychrophilum growth (more markedly for F. psychrophilum 950106-1/1), likely overshadowed the effects of the phage treatment after $24 \mathrm{~h}$. The inhibiting effect of the buffer was thought to be related to the $\mathrm{NaCl}$ concentration in this buffer $(0.6 \%)$. Previous studies have shown that F. psychrophilum can tolerate $\mathrm{NaCl}$ concentrations in the range $0.5-1.0 \%$, but these properties vary among strains $[29,64]$. However, more studies are required to assess the potential of phage control on time scales beyond $24 \mathrm{~h}$, using different incubation media that do not inhibit bacterial growth in the control cultures. The detection of F. psychrophilum colonies after the initial decrease in phage-treated groups may indicate the development of phage-resistant mutants (Figure 6A). In [60], zebrafish larvae (chosen as biological model system) exposed to phage VP-2 were characterized by a significantly lower mortality than the ones challenged with Vibrio only. The authors also observed the growth of some phage-resistant mutants of the pathogenic bacteria with a different morphology, which are generally characterized by a loss of virulence.

If F. psychrophilum growth was negatively affected by the SM buffer, a 10-fold increase in F. psychrophilum cells associated with the eyed eggs was instead detected during the $48 \mathrm{~h}$ of bathing in the Milli-Q water-control bath (Figure 6). Knowing that this bacterium does not grow actively in water, the reduced water flow was thought to stimulate the overgrowth of the pathogen on the egg surface. In addition, starved cells of F. psychrophilum have been shown to adhere to unfertilized eggs in higher numbers [65]. Moreover, no significant 
difference in the F. psychrophilum concentration was detected when including a drying step in the sampling procedure (Figure 5). All these findings suggest that these bacteria were indeed directly associated with the egg surface. Moreover, cells of F. psychrophilum 160401-1/5N adhered to the eyed eggs in a higher number than F. psychrophilum 950106-1/1 (Figure 5), suggesting that strain-specific differences in cell-adherence properties may be due to specific properties of the isolates. A previous study have shown large differences in adherence properties between different F. psychrophilum strains [31], but that analysis based on using polystyrene surfaces did not find different adhesion properties of the strains 160401-1/5N and 950106-1/1 used in the current study. Despite that, the ability to adhere to polystyrene surfaces is likely not directly comparable to their ability to colonize fish eggs.

\subsection{Phages as Control Agents for F. columnare in Eyed Eggs}

F. columnare has been found in the eggs and ovarian fluids of Chinook salmon (Oncorhynhus tshawytscha) [66,67]. Here, we tested if phage baths can control F. columnare in relation to eyed eggs, either given as prophylactic treatments or following exposure to bacteria. Although detected in the first experiments described above (Figure S1), F. columnare was not isolated from any of the medium or egg samples taken at any sampling time point in later experiments (Table 3 and Figure 8). This was probably caused by the experimental temperature $\left(10{ }^{\circ} \mathrm{C}\right)$ in those experiments, which was too low for the bacterium. Similarly, in a study by Barnes et al. (2009) [56], F. columnare was found to interact with eggs, but the bacteria had no effect on salmonid egg survival at temperatures between $10-12{ }^{\circ} \mathrm{C}$. Indeed, the adhesion, replication, and virulence characteristics of this bacterial species are strongly dependent on temperature $[16,68,69]$, and the lack of bacterial growth in our experiment hampered the assessment of the effect of phages on the prevention of this bacterium. Yet, as an encouraging fact, neither bacterial nor phage addition had any adverse effects on egg survival. Constant phage treatments yielded $10^{5}$ PFU per $\mathrm{mL}$ titers up to $48 \mathrm{~h}$. However, as mentioned above, while the optimum temperatures for F. columnare and salmonid eggs do not match, the results obtained in this study may be beneficial for warm water fish species, suggesting a need for similar experiments in such species.

\section{Conclusions}

To the authors' knowledge, the present work represents the first study exploring the potential of using bacteriophages to control Flavobacterial pathogens in relation to salmonid eyed eggs. The results demonstrated a strong potential for short term $(24 \mathrm{~h})$ phage control of F. psychrophilum colonization of rainbow trout fry eggs. However, further studies are needed to explore if phage control can be maintained beyond $24 \mathrm{~h}$ and to better understand the mechanisms of interaction between flavobacteria and their phages in connection with rainbow trout eyed eggs. For example, microscopy based methods to visualize the interactions could be used.

Supplementary Materials: The following are available online at https:/ / www.mdpi.com/article/10 .3390/microorganisms9050971/s1. Figure S1: Survival of rainbow trout eggs at different temperatures with and without exposure to F. columnare, in either water or Shieh medium (Section A); Figure S2: Exp. II, section C: survival and hatching percentage recorded at the end of the experiment (144 h).

Author Contributions: Conceptualization, L.M., I.D., L.-R.S. and M.M.; methodology, V.L.D., A.R.-S., H.K., L.M., I.D., L.-R.S. and M.M.; formal analysis, V.L.D.; investigation, V.L.D., H.K., A.R.-S., J.J. and D.C.; data curation, V.L.D., A.R.-S. and H.K.; writing-original draft preparation, V.L.D. and L.-R.S.; writing—review and editing, all authors; visualization, V.L.D.; supervision, L.M., I.D., L.-R.S. and M.M.; project administration, L.M., I.D., L.-R.S. and M.M.; funding acquisition, M.M. All authors have read and agreed to the published version of the manuscript.

Funding: This research resulted from the BONUS FLAVOPHAGE project supported by BONUS (Art 185), funded jointly by the EU, Innovation Fund Denmark and Academy of Finland. This work was also supported by grants to L.-R.S. from the Academy of Finland (\#314939) and the Jane and Aatos Erkko Foundation. 
Data Availability Statement: The data presented in this study are available in this article and in the supplementary material.

Acknowledgments: The authors would like to thank Kári Karbech Mouritsen and Petri Papponen for their excellent technical support in the laboratories. The authors would also like to thank Hans Jørn Holm, Søren Nørtoft Olesen, and Doris Mortensen (Troutex ApS, Egtved, DK), and Yrjö Lankinen at Savon Taimen Oy (Rautalampi, FI) for providing rainbow trout eyed eggs. Finally, the authors would like to thank Marcin Los from PhageCosultants Ltd. for the production of phage FCL-2 by diafiltration.

Conflicts of Interest: The authors declare no conflict of interest.

\section{Appendix A}

Table A1. Experiments in section A concerning F. psychrophilum. Characteristics of sampled eggs during Exp. no. 1, no. 2, and no. 3. hpi $=$ hours post infection. In exp. no. 1, movement and turbidity indicators of sampled eggs were not recorded at 1 and 3 hpi.

\begin{tabular}{|c|c|c|c|c|c|c|c|c|}
\hline & \multirow{2}{*}{ Time (hpi) } & \multirow{2}{*}{$\begin{array}{c}\text { Evaluated } \\
\text { Parameters }\end{array}$} & \multicolumn{3}{|c|}{ + F. psychrophilum } & \multicolumn{3}{|c|}{ - F. psychrophilum } \\
\hline & & & No. 1 & No. 2 & No. 3 & No. 1 & No. 2 & No. 3 \\
\hline \multirow{4}{*}{ Exp. no. 1} & \multirow{2}{*}{21} & Movement & $(+)$ & + & + & + & + & + \\
\hline & & Turbidity & $(+)$ & - & $(+)$ & - & - & - \\
\hline & \multirow[b]{2}{*}{25} & Movement & + & + & + & + & + & + \\
\hline & & Turbidity & $(+)$ & $(+)$ & $(+)$ & - & - & - \\
\hline \multirow{4}{*}{ Exp. no. 2} & \multirow{2}{*}{0} & Movement & + & + & + & + & + & + \\
\hline & & Turbidity & - & - & - & - & - & - \\
\hline & \multirow{2}{*}{24} & Movement & + & - & + & + & + & + \\
\hline & & Turbidity & - & $(+)$ & - & - & - & - \\
\hline \multirow{4}{*}{ Exp. no. 3} & \multirow{2}{*}{0} & Movement & + & + & + & + & + & + \\
\hline & & Turbidity & - & - & - & - & - & - \\
\hline & \multirow{2}{*}{24} & Movement & + & - & + & + & + & + \\
\hline & & Turbidity & - & - & - & - & - & - \\
\hline
\end{tabular}

+ Positive to movement or turbidity; (+) Weak movement/light turbidity; - Negative to movement or turbidity.

Table A2. Experiments in section A concerning F. psychrophilum. Bacterial growth other than F. psychrophilum in sampled eyed eggs and the corresponding bath/well. A plus symbol with an orange background indicates a positive detection of bacterial colonies in TYES-B and/or on Blood-A ("-" = no growth).

\begin{tabular}{|c|c|c|c|c|c|c|c|c|}
\hline & \multirow{2}{*}{ Time (hpi) } & \multirow{2}{*}{$\begin{array}{c}\text { Sample } \\
\text { (Medium Type) }\end{array}$} & \multicolumn{3}{|c|}{+ F. psychrophilum } & \multicolumn{3}{|c|}{-F.psychrophilum } \\
\hline & & & No. 1 & No. 2 & No. 3 & No. 1 & No. 2 & No. 3 \\
\hline \multirow{2}{*}{ Exp. no. 1} & \multirow{2}{*}{25} & Egg & n.d. & n.d. & n.d. & n.d. & n.d. & n.d. \\
\hline & & Well (Blood-A) & - & - & - & - & - & - \\
\hline \multirow{4}{*}{ Exp. no. 2} & \multirow{2}{*}{0} & Egg (TYES-A) & + & - & + & + & + & - \\
\hline & & Bath (Blood-A) & & - & & & - & \\
\hline & \multirow{2}{*}{24} & Egg (TYES-A) & - & - & - & + & + & - \\
\hline & & $\begin{array}{l}\text { Well (TYES-A; } \\
\text { Blood-A) }\end{array}$ & $-;-$ & $-;-$ & $-;-$ & $+;-$ & $-;-$ & $-;-$ \\
\hline \multirow[t]{3}{*}{ Exp. no. 3} & $\mathbf{0}$ & $\begin{array}{c}\text { Egg } \\
\text { Bath (Blood-A) }\end{array}$ & n.d. & n.d. & n.d. & n.d. & n.d. & n.d. \\
\hline & \multirow[b]{2}{*}{24} & Egg (TYES-A) & + & - & - & + & + & + \\
\hline & & Well (TYES-A) & - & - & - & + & + & + \\
\hline
\end{tabular}


Table A3. Exp. I section B. Bacterial growth in the well of sampled eyed eggs was assessed during the experiment. A plus symbol with an orange background indicates a positive detection of bacterial colonies in TYES-B and/or on Blood-A ("-" = no growth). F. psychrophilum was not detected.

\begin{tabular}{|c|c|c|c|c|c|c|c|c|c|c|c|c|c|}
\hline \multirow{3}{*}{ Time (h) } & \multirow{3}{*}{ Medium Type } & \multicolumn{6}{|c|}{$+\mathrm{FpV} 4$} & \multirow{2}{*}{\multicolumn{3}{|c|}{$\begin{array}{c}\text { + FPSV-D22 } \\
\text { PEG-Purified }\end{array}$}} & \multicolumn{3}{|c|}{ Control } \\
\hline & & \multicolumn{3}{|c|}{ Crude Lysate } & \multicolumn{3}{|c|}{ PEG-Purified } & & & & \multirow[b]{2}{*}{ No. 1} & \multirow[b]{2}{*}{ No. 2} & \multirow[b]{2}{*}{ No. 3} \\
\hline & & No. 1 & No. 2 & No. 3 & No. 1 & No. 2 & No. 3 & No. 1 & No. 2 & No. 3 & & & \\
\hline \multirow{2}{*}{2} & TYES-A & - & - & - & - & - & - & - & - & - & - & - & - \\
\hline & Blood-A & - & - & - & - & - & - & - & - & - & - & - & - \\
\hline \multirow{2}{*}{27} & TYES-A & + & - & - & + & - & - & - & - & - & - & - & - \\
\hline & Blood-A & + & - & - & + & - & - & - & - & - & - & - & - \\
\hline \multirow{2}{*}{49} & TYES-A & - & - & - & - & - & - & - & - & - & - & - & - \\
\hline & Blood-A & + & - & + & - & - & - & + & - & + & - & + & - \\
\hline \multirow{2}{*}{71} & TYES-A & & n.d. & & & n.d. & & & n.d. & & & n.d. & \\
\hline & Blood-A & - & - & - & - & - & - & - & - & - & - & - & - \\
\hline \multirow{2}{*}{144} & TYES-A & & n.d. & & & n.d. & & & n.d. & & & n.d. & \\
\hline & Blood-A & - & - & - & - & - & + & + & - & - & + & - & - \\
\hline
\end{tabular}

Table A4. Exp. II section B. Bacterial growth in the well of sampled eyed eggs was assessed during the experiment. A plus symbol with an orange background indicates a positive detection of bacterial colonies in TYES-B and/or on Blood-A ("-" = no growth). F. psychrophilum was not detected.

\begin{tabular}{|c|c|c|c|c|c|c|c|c|c|c|}
\hline \multirow{3}{*}{ Time (h) } & \multirow{3}{*}{ Medium Type } & \multicolumn{6}{|c|}{ + Crude Lysate } & \multicolumn{3}{|c|}{ Control } \\
\hline & & \multicolumn{3}{|c|}{$+\mathrm{FpV} 4$} & \multicolumn{3}{|c|}{ + FPSV-D22 } & \multirow[b]{2}{*}{ No. 1} & \multirow[b]{2}{*}{ No. 2} & \multirow[b]{2}{*}{ No. 3} \\
\hline & & No. 1 & No. 2 & No. 3 & No. 1 & No. 2 & No. 3 & & & \\
\hline \multirow{2}{*}{0 * } & TYES-A & & - & & & - & & & - & \\
\hline & Blood-A & & - & & & - & & & - & \\
\hline \multirow[b]{2}{*}{24} & TYES-A & - & - & - & - & - & - & - & - & - \\
\hline & Blood-A & - & - & - & - & - & - & - & - & - \\
\hline \multirow{2}{*}{46} & TYES-A & - & - & - & - & - & - & - & - & - \\
\hline & Blood-A & - & - & - & - & - & - & - & - & - \\
\hline \multirow{2}{*}{68} & TYES-A & & n.d. & & & n.d. & & & n.d. & \\
\hline & Blood-A & - & - & - & - & - & - & - & + & - \\
\hline \multirow{2}{*}{144} & TYES-A & & n.d. & & & n.d. & & & n.d. & \\
\hline & Blood-A & - & - & + & + & - & - & + & + & - \\
\hline
\end{tabular}

* Bath content; n.d. $=$ not determined, not sampled. 


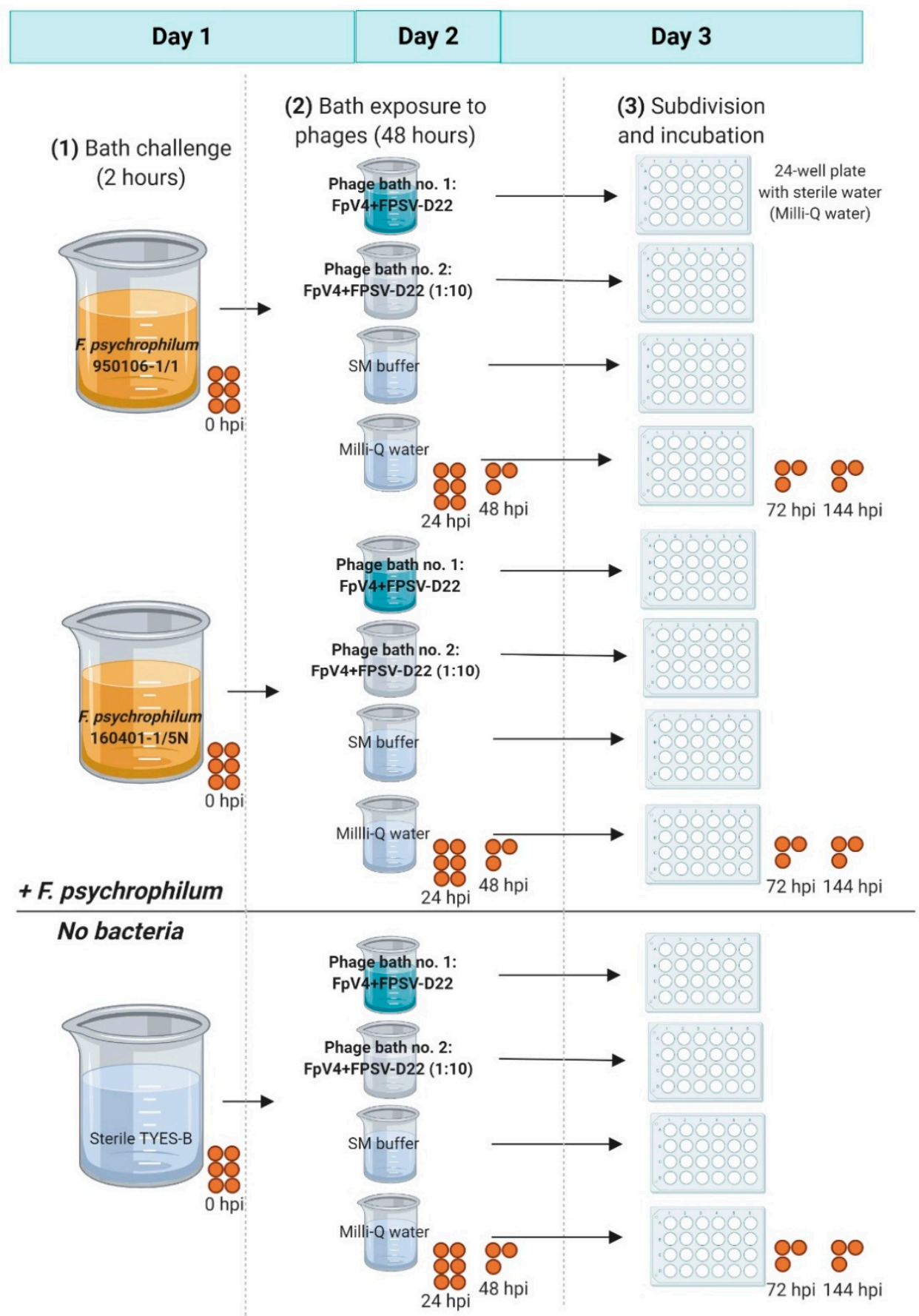

Figure A1. Exp. I section C: experimental set up. (1) Rainbow trout eyed eggs were bath-challenged for $2 \mathrm{~h}$ with either $F$. psychrophilum strain $950106-1 / 1$ or the strain $160401-1 / 5 \mathrm{~N}\left(2.0 \times 10^{6} \mathrm{CFU} \mathrm{mL}^{-1}\right)$, while control eggs were placed in sterile TYES-B. The procedure was performed in $600 \mathrm{~mL}$ sterile glass beakers containing $200 \mathrm{~mL}$ of the selected solution (135 eggs per beaker). (2) Eyed eggs were exposed to phages FpV4 and FPSV-D22 (mixed 1:1) for 48 h by bath: phage bath no. 1 (10 ${ }^{9}$ PFU mL $\left.{ }^{-1}\right)$ and phage bath no. $2\left(10^{8} \mathrm{PFU} \mathrm{mL}^{-1}\right)$. Phage bath controls with SM buffer and Milli-Q water were included. The procedure was performed in $250 \mathrm{~mL}$ sterile glass beakers (30 eggs per beaker) containing the selected solution (20 $\mathrm{mL}$ ). (3) Eyed eggs were divided in 24-well plates containing $2 \mathrm{~mL}$ of sterile Milli-Q water (one egg per well). For each step, eyed eggs were incubated at $10{ }^{\circ} \mathrm{C}$ at 80-90 RPM. Eyed eggs were sampled during the experiment as indicated by the round orange circles resembling trout eyed eggs. At 0 and $24 \mathrm{hpi}$, six eggs were sampled to compare the standard sampling procedure to the one including a drying step. hpi = hours post infection. Created with Biorender.com (the figure was exported under a paid license subscription). 


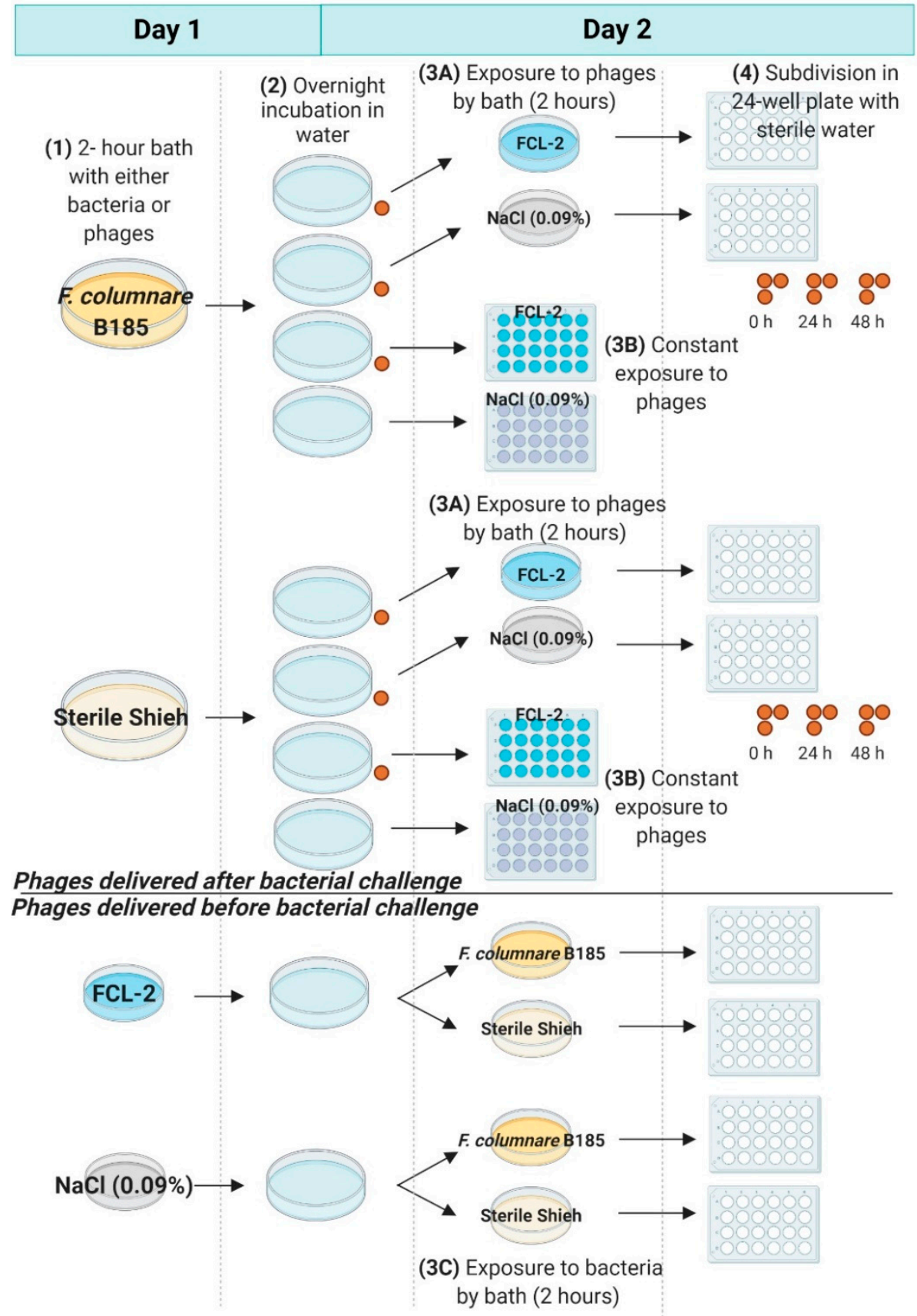

Figure A2. Exp. II section C: experimental set up. Rainbow trout eyed eggs were exposed to phages after (upper panel) or before bacterial challenge (lower panel). (1) Eyed eggs were bathed for $2 \mathrm{~h}$ with F. columnare B185 $\left(5.0 \times 10^{6} \mathrm{CFU} \mathrm{mL}^{-1}\right)$ or sterile Shieh medium (upper panel) in $140 \mathrm{~mm} \varnothing$ Petri dishes (97-99 eggs per dish-100 mL volume), and with the phage FCL-2 $\left(2.5 \times 10^{7} \mathrm{PFU} \mathrm{mL}{ }^{-1}\right)$ or $\mathrm{NaCl}(0.09 \%)$ (lower panel) in $90 \mathrm{~mm} \varnothing$ Petri dishes (24 eggs per dish-35 mL volume). (2) Eggs were moved into $140 \mathrm{~mm} \varnothing$ Petri dishes (22-25 eggs per dish-100 mL volume) with water and incubated overnight. (3) Eyed eggs previously exposed to $F$. columnare were either (3A) bathed for $2 \mathrm{~h}$ or (3B) moved directly into 24-well plates in either FCL-2 phage solution $\left(2.5 \times 10^{7} \mathrm{PFU} \mathrm{mL}^{-1}\right)$ or $\mathrm{NaCl}(0.09 \%)$ (24 eggs per group) (upper panel). (3C) Eyed eggs previously exposed to phages were bath-exposed to F. columnare strain B185 $\left(5.0 \times 10^{6} \mathrm{CFU} \mathrm{mL}{ }^{-1}\right)$ or sterile Shieh medium for $2 \mathrm{~h}$ (12 eggs per group) (lower panel). Bath exposures to either phages or bacteria were performed in $90 \mathrm{~mm} \varnothing \mathrm{Petri}$ dishes (35 mL volume). (4) Following the $2 \mathrm{~h}$ bath, eyed eggs were transferred into 24-well plates containing $2 \mathrm{~mL}$ of water (one per well). Eyed eggs were sampled during the experiment as indicated by the round orange circles resembling trout eyed eggs. $\mathrm{h}$ = hours post phage exposure. Created with Biorender.com (the figure was exported under a paid license subscription). 


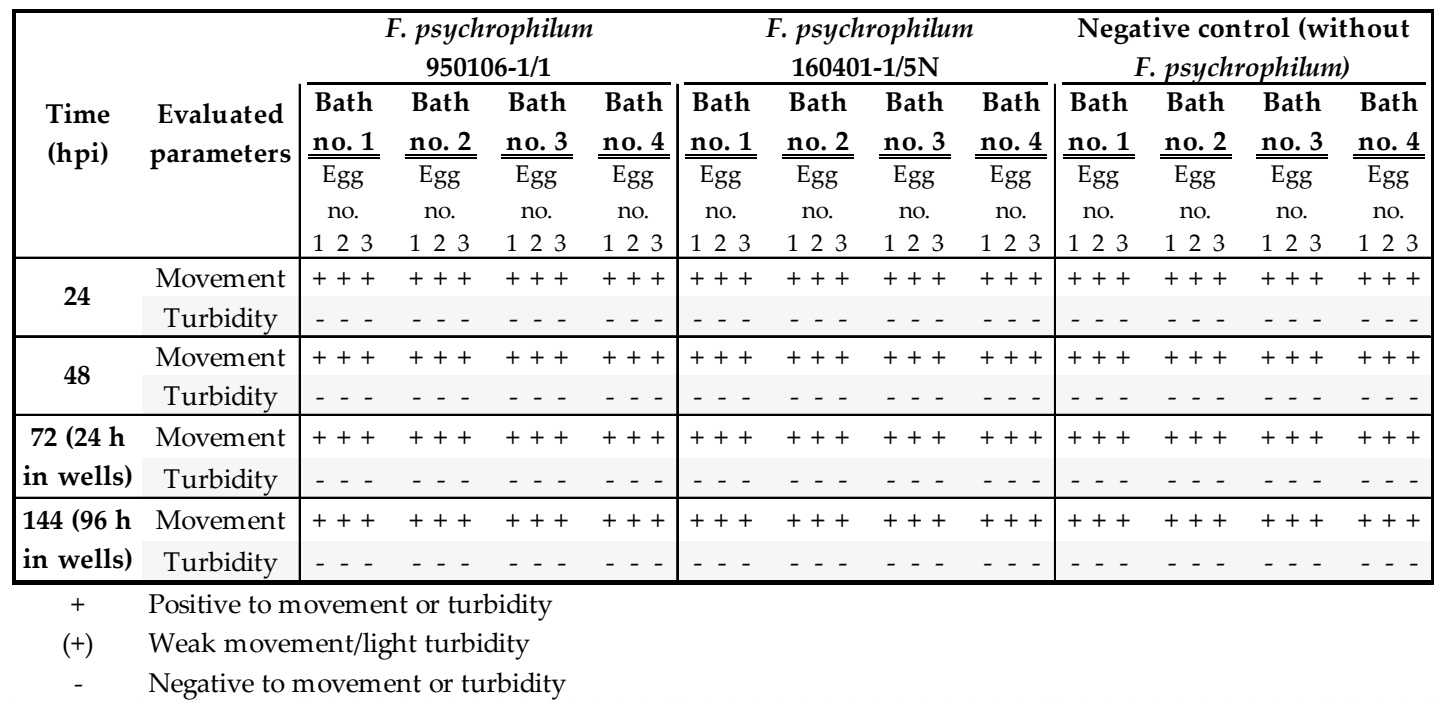

Figure A3. Exp. I section C: characteristics of sampled eggs. hpi = hours post infection. Bath no. 1: phage bath with of $10^{9}$ PFU mL ${ }^{-1}$; Bath no. 2: phage bath with $10^{8}$ PFU mL ${ }^{-1}$; Bath no. 3: control bath with SM buffer; Bath no. 4: control bath with Milli-Q water.

\begin{tabular}{|c|c|c|c|c|c|c|c|c|c|c|c|c|c|c|}
\hline \multirow{4}{*}{$\begin{array}{l}\text { Time } \\
\text { (hpi) }\end{array}$} & \multirow{4}{*}{ Sample } & \multirow{4}{*}{$\begin{array}{l}\text { Type of } \\
\text { medium }\end{array}$} & \multicolumn{4}{|c|}{$\begin{array}{c}\text { F. psychrophilum } \\
950106-1 / 1 \\
\end{array}$} & \multicolumn{4}{|c|}{$\begin{array}{l}\text { F. psychrophilum } \\
160401-1 / 5 \mathrm{~N}\end{array}$} & \multicolumn{4}{|c|}{$\begin{array}{c}\text { Negative control (without } \\
\text { F. psychrophilum) }\end{array}$} \\
\hline & & & $\begin{array}{l}\text { Bath } \\
\text { no. } 1 \\
\end{array}$ & $\begin{array}{l}\text { Bath } \\
\text { no. } 2 \\
\end{array}$ & $\begin{array}{r}\text { Bath } \\
\text { no. } 3 \\
\end{array}$ & $\begin{array}{l}\text { Bath } \\
\text { no. } 4 \\
\end{array}$ & $\begin{array}{l}\text { Bath } \\
\text { no. } 1 \\
\end{array}$ & $\begin{array}{l}\text { Bath } \\
\text { no. } 2 \\
\end{array}$ & $\begin{array}{l}\text { Bath } \\
\text { no. } 3 \\
\end{array}$ & $\begin{array}{l}\text { Bath } \\
\text { no. } 4 \\
\end{array}$ & $\begin{array}{l}\text { Bath } \\
\text { no. } 1 \\
\end{array}$ & $\begin{array}{l}\text { Bath } \\
\text { no. } 2 \\
\end{array}$ & $\begin{array}{l}\text { Bath } \\
\text { no. } 3 \\
\end{array}$ & $\begin{array}{l}\text { Bath } \\
\text { no. } 4 \\
\end{array}$ \\
\hline & & & no. & no. & no. & no. & no. & no. & no. & no. & no. & no. & no. & no. \\
\hline & & & 123 & 123 & 123 & 123 & 123 & 123 & 123 & 123 & 123 & 123 & 123 & 123 \\
\hline \multirow{4}{*}{24} & \multirow{2}{*}{ Egg } & & +-- & -- & -- & -+- & -- & +++ & --+ & -- & -- & -- & -- & -- \\
\hline & & Blood-A & -- & + & - - & $\ldots$ & + & - - - & - - - & - - - & - - - & - - & - - - & - - - \\
\hline & \multirow{2}{*}{ Bath } & TYES-A & - & - & - & - & - & + & - & - & - & - & - & - \\
\hline & & Blood-A & - & - & - & - & - & + & - & - & - & - & - & - \\
\hline \multirow{4}{*}{48} & \multirow{2}{*}{ Egg } & TYES-A & $-\cdots$ & $-\cdots$ & -+ & -- & +++ & +++ & -- & +-+ & -- & -- & -+- & -- \\
\hline & & Blood-A & --- & -- & +-- & --- & --- & $--\cdot$ & --- & $--\cdot$ & -- & -- & --- & $--\cdot$ \\
\hline & \multirow{2}{*}{ Bath } & TYES-A & - & - & + & - & - & + & - & + & - & - & - & - \\
\hline & & Blood-A & - & - & - & - & - & + & - & - & - & - & - & - \\
\hline \multirow{4}{*}{$\begin{array}{c}72 \\
(24 \mathrm{~h} \\
\text { in } \\
\text { wells })\end{array}$} & \multirow{2}{*}{ Egg } & TYES-A & +++ & +++ & +++ & +++ & +++ & +++ & +++ & +++ & -+ & ++ & -- & +++ \\
\hline & & Blood-A & +++ & +++ & +++ & +++ & ++- & +++ & +++ & +++ & +++ & +++ & +++ & -+- \\
\hline & \multirow{2}{*}{ Well } & TYES-A & -++ & -- & --+ & -- & +-- & +++ & -- & +++ & -- & -- & -- & -- \\
\hline & & Blood-A & -- & -- & -- & -- & --- & +++ & -- & -- & -- & -- & -- & -- \\
\hline \multirow{4}{*}{$\begin{array}{c}144 \\
(96 \mathrm{~h} \\
\text { in } \\
\text { wells })\end{array}$} & \multirow{2}{*}{ Egg } & TYES-A & +++ & ++++ & ++++ & +++ & +++ & +++ & +++ & +++ & +++ & ++++ & +++ & ++++ \\
\hline & & Blood-A & +++ & +++ & +++ & +++ & +++ & +++ & +++ & +++ & +-+ & +++ & ++- & +++ \\
\hline & \multirow{2}{*}{ Well } & TYES-A & +-- & -+- & +++ & +++ & +++ & +++ & -- & +++ & -- & -- & +- & +++ \\
\hline & & Blood-A & +++ & -+- & +++ & +++ & +++ & +++ & -+- & +++ & --- & -- & -- & -- \\
\hline
\end{tabular}

Figure A4. Exp. I section C: bacterial growth other than F. psychrophilum in sampled eyed eggs and the corresponding bath/wells was recorded. A plus symbol with an orange background indicates a positive detection of bacterial colonies in TYES-B and/or on Blood-A ("-" = no growth). Bath no. 1: phage bath with of $10^{9} \mathrm{PFU} \mathrm{mL}{ }^{-1}$; Bath no. 2: phage bath with $10^{8} \mathrm{PFU} \mathrm{mL}^{-1}$; Bath no. 3: control bath with SM buffer; Bath no. 4: control bath with Milli-Q water.

\section{References}

1. Groot, E.P.; Alderdice, D.F. Fine structure of the external egg membrane of five species of Pacific salmon and steelhead trout. Can. J. Zool. 1985, 63, 552-566. [CrossRef]

2. Llewellyn, M.S.; Boutin, S.; Hoseinifar, S.H.; Derome, N. Teleost microbiomes: The state of the art in their characterization, manipulation and importance in aquaculture and fisheries. Front. Microbiol. 2014, 5, 207. [CrossRef]

3. Hansen, G.H.; Olafsen, J.A. Bacterial Interactions in Early Life Stages of Marine Cold Water Fish. Microb. Ecol. 1999, 38, 1-26. [CrossRef] 
4. Sauter, R.W.; Williams, C.; Meyer, E.A.; Celnik, B.; Banks, J.L.; Leith, D.A. A study of bacteria present within unfertilized salmon eggs at the time of spawning and their possible relation to early lifestage disease. J. Fish Dis. 1987, 10, 193-203. [CrossRef]

5. Trust, T.J. The Bacterial Population in Vertical Flow Tray Hatcheries During Incubation of Salmonid Eggs. J. Fish. Res. Board Can. 1972, 29, 567-571. [CrossRef]

6. Hansen, G.H.; Olafsen, J.A. Bacterial Colonization of Cod (Gadus morhua L.) and Halibut (Hippoglossus hippoglossus) Eggs in Marine Aquaculture. Appl. Environ. Microbiol. 1989, 55, 1435-1446. [CrossRef] [PubMed]

7. De Swaef, E.; Broeck, W.V.D.; Dierckens, K.; Decostere, A. Disinfection of teleost eggs: A review. Rev. Aquac. 2016, 8, 321-341. [CrossRef]

8. Borg, A.F. Studies on Myxobacteria Associated with Diseases in Salmonid Fishes. Ph.D. Thesis, University of Washington, Seattle, WA, USA, 1948.

9. Bernardet, J.-F.; Segers, P.; Vancanneyt, M.; Berthe, F.; Kersters, K.; Vandamme, P. Cutting a Gordian Knot: Emended Classification and Description of the Genus Flavobacterium, Emended Description of the Family Flavobacteriaceae, and Proposal of Flavobacterium hydatis nom. nov. (Basonym, Cytophaga aquatilis Strohl and Tait 1978). Int. J. Syst. Bacteriol. 1996, 46, 128-148. [CrossRef]

10. Madsen, L.; Dalsgaard, I. Comparative studies of Danish Flavobacterium psychrophilum isolates: Ribotypes, plasmid profiles, serotypes and virulence. J. Fish Dis. 2000, 23, 211-218. [CrossRef]

11. Nematollahi, A.; Decostere, A.; Pasmans, F.; Haesebrouck, F. Flavobacterium psychrophilum infections in salmonid fish. J. Fish Dis. 2003, 26, 563-574. [CrossRef]

12. Madsen, L.; Møller, J.D.; Dalsgaard, I. Flavobacterium psychrophilum in rainbow trout, Oncorhynchus mykiss (Walbaum), hatcheries: Studies on broodstock, eggs, fry and environment. J. Fish Dis. 2005, 28, 39-47. [CrossRef]

13. Rangdale, R.E.; Richards, R.E.; Alderman, D.J. Isolation of Cytophaga psychrophila, causal agent of Rainbow Trout Fry Syndrome (RTFS) from reproductive fluids and egg surfaces of rainbow trout (Oncorhynchus mykiss). Bull. Eur. Ass. Fish Pathol. 1996, 16, 63-67.

14. Brown, L.; Cox, W.; Levine, R. Evidence that the causal agent of bacterial cold-water disease Flavobacterium psychrophilum is transmitted within salmonid eggs. Dis. Aquat. Org. 1997, 29, 213-218. [CrossRef]

15. Madsen, L.; Dalsgaard, I. Water recirculation and good management: Potential methods to avoid disease outbreaks with Flavobacterium psychrophilum. J. Fish Dis. 2008, 31, 799-810. [CrossRef]

16. Declercq, A.M.; Haesebrouck, F.; Broeck, W.V.D.; Bossier, P.; Decostere, A. Columnaris disease in fish: A review with emphasis on bacterium-host interactions. Veter. Res. 2013, 44, 27. [CrossRef] [PubMed]

17. Lorenzen, E. Studies on Flexibacter psychrophilus in Relation to Rainbow Trout Fry Syndrome (RTFS). Ph.D. Thesis, National Veterinary Laboratory, Århus \& Royal Veterinary and Agricultural University, Copenhagen, Denmark, 1994.

18. Nilsen, H.; Olsen, A.B.; Vaagnes, Ø.; Hellberg, H.; Bottolfsen, K.; Skjelstad, H.; Colquhoun, D.J. Systemic Flavobacterium psychrophilum infection in rainbow trout, Oncorhynchus mykiss (Walbaum), farmed in fresh and brackish water in Norway. J. Fish Dis. 2011, 34, 403-408. [CrossRef] [PubMed]

19. Suomalainen, L.-R.; Tiirola, M.A.; Valtonen, E.T. Effect of Pseudomonas sp. MT5 baths on Flavobacterium columnare infection of rainbow trout and on microbial diversity on fish skin and gills. Dis. Aquat. Org. 2005, 63, 61-68. [CrossRef] [PubMed]

20. Salmond, G.P.C.; Fineran, P.C. A century of the phage: Past, present and future. Nat. Rev. Genet. 2015, 13, 777-786. [CrossRef]

21. Culot, A.; Grosset, N.; Gautier, M. Overcoming the challenges of phage therapy for industrial aquaculture: A review. Aquaculture 2019, 513, 734423. [CrossRef]

22. Kowalska, J.D.; Kazimierczak, J.; Sowińska, P.M.; Wójcik, E.A.; Siwicki, A.K.; Dastych, J. Growing Trend of Fighting Infections in Aquaculture Environment-Opportunities and Challenges of Phage Therapy. Antibiotics 2020, 9, 301. [CrossRef]

23. Rao, B.M.; Lalitha, K. Bacteriophages for aquaculture: Are they beneficial or inimical. Aquaculture 2015, 437, 146-154. [CrossRef]

24. Christiansen, R.H.; Dalsgaard, I.; Middelboe, M.; Lauritsen, A.H.; Madsen, L. Detection and Quantification of Flavobacterium psychrophilum-Specific Bacteriophages In Vivo in Rainbow Trout upon Oral Administration: Implications for Disease Control in Aquaculture. Appl. Environ. Microbiol. 2014, 80, 7683-7693. [CrossRef] [PubMed]

25. Madsen, L.; Bertelsen, S.K.; Dalsgaard, I.; Middelboe, M. Dispersal and Survival of Flavobacterium psychrophilum Phages In Vivo in Rainbow Trout and In Vitro under Laboratory Conditions: Implications for Their Use in Phage Therapy. Appl. Environ. Microbiol. 2013, 79, 4853-4861. [CrossRef]

26. Castillo, D.; Higuera, G.; Villa, M.; Middelboe, M.; Dalsgaard, I.; Madsen, L.; Espejo, R.T. Diversity of Flavobacterium psychrophilum and the potential use of its phages for protection against bacterial cold water disease in salmonids. J. Fish Dis. 2012, 35, 193-201. [CrossRef] [PubMed]

27. Donati, V.L.; Dalsgaard, I.; Sundell, K.; Castillo, D.; Er-Rafik, M.; Clark, J.; Wiklund, T.; Middelboe, M.; Madsen, L. Phage-Mediated Control of Flavobacterium psychrophilum in Aquaculture: In vivo Experiments to Compare Delivery Methods. Front. Microbiol. 2021, 12. [CrossRef] [PubMed]

28. Elaanto, E.; Bamford, J.K.H.; Ravantti, J.J.; Esundberg, L.-R. The use of phage FCL-2 as an alternative to chemotherapy against columnaris disease in aquaculture. Front. Microbiol. 2015, 6, 829. [CrossRef]

29. Dalsgaard, I.; Madsen, L. Bacterial pathogens in rainbow trout, Oncorhynchus mykiss (Walbaum), reared at Danish freshwater farms. J. Fish Dis. 2000, 23, 199-209. [CrossRef]

30. Madsen, L.; Dalsgaard, I. Reproducible methods for experimental infection with Flavobacterium psychrophilum in rainbow trout Oncorhynchus mykiss. Dis. Aquat. Org. 1999, 36, 169-176. [CrossRef] [PubMed] 
31. Sundell, K.; Landor, L.; Nicolas, P.; Jørgensen, J.; Castillo, D.; Middelboe, M.; Dalsgaard, I.; Donati, V.L.; Madsen, L.; Wiklund, T. Phenotypic and Genetic Predictors of Pathogenicity and Virulence in Flavobacterium psychrophilum. Front. Microbiol. 2019, $10,1711$. [CrossRef] [PubMed]

32. Holt, R.A.; Rohovec, J.S.; Fryer, J.L. Bacterial cold-water disease. Bact. Dis. Fish 1993, 3-22.

33. Runtuvuori-Salmela, A.; Kunttu, H.M.T.; Laanto, E.; Almeida, G.M.F.; Mäkelä, K.; Middelboe, M.; Sundberg, L.-R. Prevalence of genetically similar Flavobacterium columnare phages across aquaculture environments reveals a strong potential for pathogen control. bioRxiv 2020. [CrossRef]

34. Laanto, E.; Sundberg, L.-R.; Bamford, J.K.H. Phage Specificity of the Freshwater Fish Pathogen Flavobacterium columnare. Appl. Environ. Microbiol. 2011, 77, 7868-7872. [CrossRef]

35. Song, Y.L.; Fryer, J.L.; Rohovec, J.S. Comparison of six media for the cultivation of Flexibacter columnaris. Fish Pathol. 1988, 23, 91-94. [CrossRef]

36. Stenholm, A.R.; Dalsgaard, I.; Middelboe, M. Isolation and Characterization of Bacteriophages Infecting the Fish Pathogen Flavobacterium psychrophilum. Appl. Environ. Microbiol. 2008, 74, 4070-4078. [CrossRef]

37. Castillo, D.; Middelboe, M. Genomic diversity of bacteriophages infecting the fish pathogen Flavobacterium psychrophilum. FEMS Microbiol. Lett. 2016, 363, fnw272. [CrossRef] [PubMed]

38. Castillo, D.; Andersen, N.; Kalatzis, P.G.; Middelboe, M. Large Phenotypic and Genetic Diversity of Prophages Induced from the Fish Pathogen Vibrio anguillarum. Viruses 2019, 11, 983. [CrossRef] [PubMed]

39. Cipriano, R.C. Intraovum Infection Caused by Flavobacterium psychrophilum among Eggs from Captive Atlantic Salmon Broodfish. J. Aquat. Anim. Health 2005, 17, 275-283. [CrossRef]

40. Cipriano, R.C. Bacterial Analysis of Fertilized Eggs of Atlantic Salmon from the Penobscot, Naraguagus, and Machias Rivers, Maine. J. Aquat. Anim. Health. 2015, 27, 172-177. [CrossRef]

41. Cipriano, R.C.; Ford, L.A.; Teska, J.D. Association of Cytophaga psychrophila with mortality among eyed eggs of Atlantic Salmon (Salmo salar). J. Wildl. Dis. 1995, 31, 166-171. [CrossRef]

42. Jansson, E.; Haenen, O.L.M.; Nonnemann, B.; Madsen, L.; Gelderen, v.E.; Aspán, A.; Säker, E.; Boonstra, M.; Gulla, S.; Colquhoun, D.J. MALDI-TOF MS: A diagnostic tool for identification of bacterial fish pathogens. Bull. Eur. Ass. Fish Pathol. 2020, 40, $240-248$.

43. Clokie, M.R.J.; Kropinski, A.M. (Eds.) Bacteriophages: Methods and Protocols, Volume 1: Isolation, Characterization, and Interactions, vol. 501; Humana Press, a part of Springer Science+Business Media: New York, NY, USA, 2009. [CrossRef]

44. Ashrafi, R.; Bruneaux, M.; Sundberg, L.-R.; Pulkkinen, K.; Valkonen, J.; Ketola, T. Broad thermal tolerance is negatively correlated with virulence in an opportunistic bacterial pathogen. Evol. Appl. 2018, 11, 1700-1714. [CrossRef] [PubMed]

45. Woynarovich, G.; Hoitsy, A.; Moth-Poulsen, T. Small-Scale Rainbow Trout Farming; FAO Fisheries and Aquaculture Technical Paper No. 561; FAO: Rome, Italy, 2011; 81p.

46. Rangdale, R.E.; Richards, R.H.; Alderman, D.J. Colonization of eyed rainbow trout ova with Flavobacterium psychrophilum leads to rainbow trout fry syndrome in fry. Bull. Eur. Ass. Fish Pathol. 1997, 17, 108-111.

47. Ekman, E.; Åkerman, G.; Balk, L.; Norrgren, L. Nanoinjection as a tool to mimic vertical transmission of Flavobacterium psychrophilum in rainbow trout Oncorhynchus mykiss. Dis. Aquat. Org. 2003, 55, 93-99. [CrossRef] [PubMed]

48. Barnes, M.E. A Review of Flavobacterium psychrophilum Biology, Clinical Signs, and Bacterial Cold Water Disease Prevention and Treat. Open Fish Sci. J. 2011, 4, 40-48. [CrossRef]

49. Vatsos, I.; Thompson, K.; Adams, A. Starvation of Flavobacterium psychrophilum in broth, stream water and distilled water. Dis. Aquat. Org. 2003, 56, 115-126. [CrossRef] [PubMed]

50. Madetoja, J.; Nystedt, S.; Wiklund, T. Survival and virulence of Flavobacterium psychrophilum in water microcosms. FEMS Microbiol. Ecol. 2003, 43, 217-223. [CrossRef] [PubMed]

51. Sundberg, L.-R.; Kunttu, H.M.T.; Valtonen, E.T. Starvation can diversify the population structure and virulence strategies of an environmentally transmitting fish pathogen. BMC Microbiol. 2014, 14, 67. [CrossRef] [PubMed]

52. FINEFISH Collective Research Project Consortium. Control of Malformations in Fish Aquaculture. Science and Practice. 2009. Available online: http:/ / feap.info/index.php/about/projects/ (accessed on 27 February 2021).

53. Evenhuis, J.P.; Lipscomb, R.; Birkett, C. Virulence variations of Flavobacterium columnare in rainbow trout (Oncorhynchus mykiss) eyed eggs and alevin. J. Fish Dis. 2021, 1-7. [CrossRef]

54. Dong, H.T.; LaFrentz, B.; Pirarat, N.; Rodkhum, C. Phenotypic characterization and genetic diversity of Flavobacterium columnare isolated from red tilapia, Oreochromis sp., in Thailand. J. Fish Dis. 2015, 38, 901-913. [CrossRef]

55. Barony, G.M.; Tavares, G.C.; Assis, G.B.N.; Luz, R.K.; Figueiredo, H.C.P.; Leal, C.A.G. New hosts and genetic diversity of Flavobacterium columnare isolated from Brazilian native species and Nile tilapia. Dis. Aquat. Org. 2015, 117, 1-11. [CrossRef]

56. Barnes, M.E.; Bergmann, D.; Jacobs, J.; Gabel, M. Effect of Flavobacterium columnare inoculation, antibiotic treatments and resident bacteria on rainbow trout Oncorhynchus mykiss eyed egg survival and external membrane structure. J. Fish Biol. 2009, 74, 576-590. [CrossRef] [PubMed]

57. Al-Harbi, A.H.; Uddin, M.N. Seasonal variation in the intestinal bacterial flora of hybrid tilapia (Oreochromis niloticus $\times$ Oreochromis aureus) cultured in earthen ponds in Saudi Arabia. Aquaculture 2004, 229, 37-44. [CrossRef]

58. Rørbo, N.; Rønneseth, A.; Kalatzis, P.G.; Rasmussen, B.B.; Engell-Sørensen, K.; Kleppen, H.P.; Wergeland, H.I.; Gram, L.; Middelboe, M. Exploring the Effect of Phage Therapy in Preventing Vibrio anguillarum Infections in Cod and Turbot Larvae. Antibiotics 2018, 7, 42. [CrossRef] 
59. Zawada, A.; Polechoński, R.; Bronowska, A. Iodine Disinfection of Sea Trout, Salmo Trutta (L.), Eggs and the Affect on Egg Surfaces. Arch. Pol. Fish. 2014, 22, 121-126. [CrossRef]

60. Silva, Y.J.; Costa, L.; Pereira, C.; Mateus, C.; Cunha, Â.; Calado, R.; Gomes, N.C.M.; Pardo, M.A.; Hernandez, I.; Almeida, A. Phage Therapy as an Approach to Prevent Vibrio anguillarum Infections in Fish Larvae Production. PLoS ONE 2014, 9, e114197. [CrossRef] [PubMed]

61. Yamagami, K. 7 Mechanisms of Hatching in Fish. Fish Physiol. 1988, 11, 447-499. [CrossRef]

62. Castillo, D.; Jørgensen, J.; Sundell, K.; Madsen, L.; Dalsgaard, I.; Wiklund, T.; Middelboe, M. Genome-informed approach to identify genetic determinants of Flavobacterium psychrophilum phage susceptibility. Environ. Microbiol. 2021. in review.

63. Almeida, G.M.F.; Laanto, E.; Ashrafi, R.; Sundberg, L.-R. Bacteriophage Adherence to Mucus Mediates Preventive Protection against Pathogenic Bacteria. mBio 2019, 10, e01984-19. [CrossRef] [PubMed]

64. Bernardet, J.F.; Kerouault, B. Phenotypic and genomic studies of "Cytophaga psychrophila" isolated from diseased rainbow trout (Oncorhynchus mykiss) in France. Appl. Environ. Microbiol. 1989, 55, 1796-1800. [CrossRef] [PubMed]

65. Vatsos, I.; Thompson, K.; Adams, A. Adhesion of the fish pathogen Flavobacterium psychrophilum to unfertilized eggs of rainbow trout (Oncorhynchus mykiss) and n-hexadecane. Lett. Appl. Microbiol. 2001, 33, 178-182. [CrossRef]

66. Barnes, M.; Bergmann, D.; Stephenson, H.; Gabel, M.; Cordes, R. Bacterial Numbers from Landlocked Fall Chinook Salmon Eyed Eggs Subjected to Various Formalin Treatments as Determined by Scanning Electron Microscopy and Bacteriological Culture Methods. N. Am. J. Aquac. 2005, 67, 23-33. [CrossRef]

67. Loch, T.P.; Faisal, M. Gamete-associated flavobacteria of the oviparous Chinook salmon (Oncorhynchus tshawytscha) in lakes Michigan and Huron, North America. J. Microbiol. 2016, 54, 477-486. [CrossRef] [PubMed]

68. Suomalainen, L.-R.; Tiirola, A.M.; Valtonen, E.T. Influence of rearing conditions on Flavobacterium columnare infection of rainbow trout, Oncorhynchus mykiss (Walbaum). J. Fish Dis. 2005, 28, 271-277. [CrossRef]

69. Cai, W.; De La Fuente, L.; Arias, C.R. Biofilm Formation by the Fish Pathogen Flavobacterium columnare: Development and Parameters Affecting Surface Attachment. Appl. Environ. Microbiol. 2013, 79, 5633-5642. [CrossRef] [PubMed] 